\title{
Sustained unsustainability? An evaluation of evidence for a history of overcutting in the jarrah forests of Western Australia and its consequences for fauna conservation
}

\author{
Michael Calver' and Grant Wardell-Johnson ${ }^{2}$ \\ 'Biological Sciences, Murdoch University, Murdoch, Western Australia 6I50 \\ ${ }^{2}$ Natural and Rural Systems Management, The University Of Queensland, Gatton, Gatton 3434 \\ Correspondence to M C Calver - Fax +6I 9360 6303. E-mail - m.calver@murdoch.edu.au
}

\begin{abstract}
In 1996, Government directives began a transition to conform logging in Western Australia's State forests to principles of ecologically sustainable forest management (ESFM). To place this in a historical context, we reviewed the history of the logging of jarrah Eucalyptus marginata forests to determine whether the volume of timber extracted and the main forest management practices employed was consistent with components of ESFM. While quantitative assessment proved difficult, usually the timber cut considerably exceeded the estimated annual increment of forested lands. Overcutting often distressed professionals, who strove to regulate logging despite social, political and economic pressures. Furthermore, despite recent major reductions in permissible timber cut, areas of productive State forest have declined after conversion to alternative vestings. Thus it is important to prevent overcutting continuing in the remaining production forests.

Too few data exist on the health or condition of forest ecosystems before logging to document subtle impacts. However, overcutting has interacted with broad-scale threatening processes in their impacts on forest fauna. These changes are all associated with reluctance to invoke effective adaptive management in association with the precautionary principle. The historical survey suggests that ESFM cannot be achieved without a socio-political will to assert long-term sustainable practice in the face of short-term goals. This could be achieved in the current preparation of a new forest management plan for Western Australia.
\end{abstract}

Key words: Adaptive management, ecologically sustainable forest management, ecosystem health, ecosystem management, hardwood forests, jarrah, precautionary principle.

\section{Introduction}

With proper forest management and sound sylvicultural [sic] treatment there is no reason why there should not be built up on the wreckage of the once splendid forests of Western Australia tended forests which will yield for all time 100 cubic feet of timber per acre per year. Lane Poole, WA Conservator of Forests (1920a, p. 31)

If the growth rate in the forest can be improved by good silviculture and good forest management, the allowable yield or cut will be consequently increased. Conversely any cutting beyond the capacity of the forest because of unusual demands at any time can only be made at the expense of the future output from the forests. Rodger, Report of the 1952 Royal Commission (1952, p.20)

It seems to the Inquiry that for much of its history the native forest sawn timber industry has been in disequilibrium with the supply of its raw material. In most years there seem to have been too many mills for the timber on offer. Milling capacity has almost always been greater than the supply of logs to the mills. Individual mills dependent on native forest, and the groups of such mills that go to make up 'timber towns', can survive only if the forest within their radius of extraction is managed on a sustained-yield basis. So far as the Inquiry is aware, this has never happened in Australia. Resource Assessment Commission Draft Report (1991, p. 1)

Australian forests are of global concern because of their unique biota (Wardell-Johnson and Horwitz 1996, Gioia and Piggott 2000), yet they are under substantial pressure for timber production, recreation and ecological services such as biodiversity conservation and protection of water catchments (RAC 1991, 1992; Recher 1996). Despite intense debates over forest management practices, many authors concluded, albeit with important qualifications, that eucalypt forests can be logged while sustaining forest biota and fundamental ecological processes (e.g., McIlroy 1978; Davey and Norton 1990; Attiwill 1994; Braithwaite 1996; Florence 1996; Eyre and Smith 1997; Lindenmayer and Franklin 2000, 2002). However, there is also concern that sustainability in forest management is not yet achieved and that important components of forest biota or critical ecosystem services could be compromised (e.g., Wardell-Johnson and Nichols 1991; Norton and Kirkpatrick 1995; Norton 1996; Calver et al. 1998; Lindenmayer and Recher 1998). 


\section{Western Australia is no exception:}

For many years past Western Australia has been engaged in destroying an asset which is clearly the property of the nation, that is to say, the property of all future generations. Instead of regulating the cutting timber so as to confine it to a quantity such that the forests could reproduce again, milling firms have been allowed to cut practically without restraint; in fact, they have been encouraged to cut as much as possible, and have been penalised when they did not maintain their output, with the result that the timber assets of the State have been depleted to an alarming extent. Lane Poole (1918, p. 1)

Growing pressure against such waste led to Royal Commissions in 1877 and 1903, and ultimately the passing of a Forests Act in 1918. This established a Forests Department and began the progressive designation of large areas of the south-west of Western Australia as State forest for the sustainable production of timber in perpetuity. Assessing the success of Western Australian management of jarrah Eucalyptus marginata, the main timber species, is a valuable case study with Australiawide implications. It reveals conflicting issues that must be reconciled, the evolution of concepts of sustainability and the success or otherwise of various approaches attempted. Furthermore, it clarifies the origins of current disputes and suggests resolutions through an understanding of the successes and failures of the past.

In this paper we overview briefly the biogeography of the jarrah forests before developing an approach for assessing timber yield, a fundamental base of ESFM, over the historical period in question. We then outline the history of forest management in Western Australia and determine the extent to which forest management

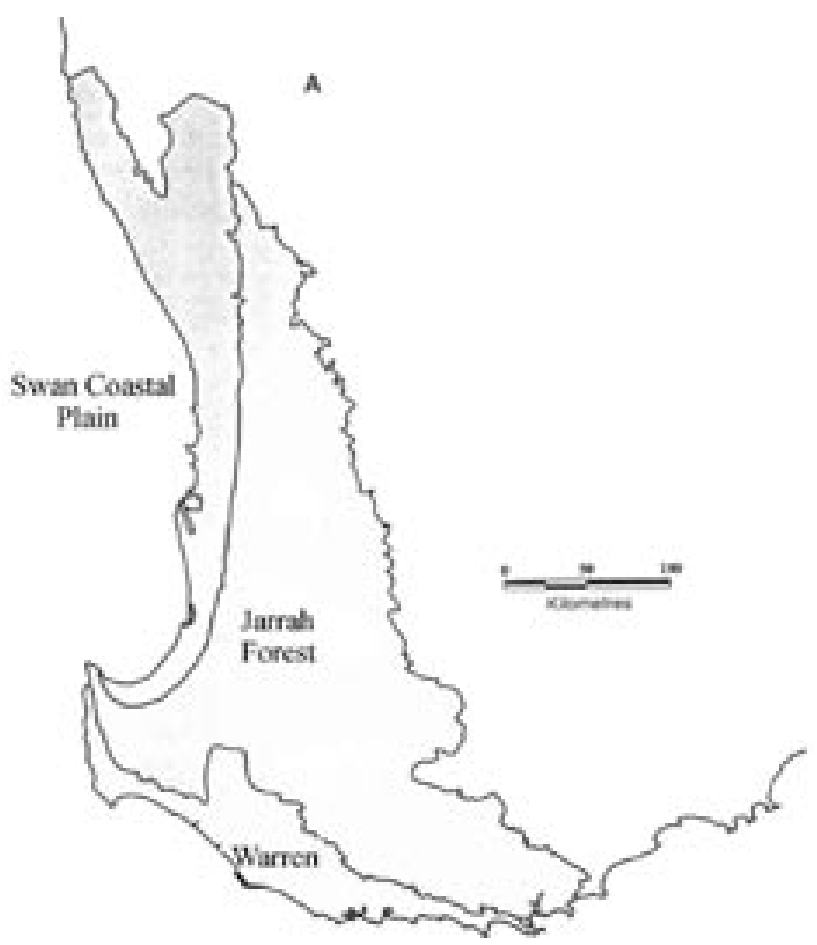

matched contemporary understandings of responsible practice at different points in the past. The political and social pressures responsible for the management adopted are then discussed, followed by an assessment of the ecological consequences likely from the accompanying structural and biophysical changes. Lastly, in the light of the historical overview, we discuss the managerial, political and institutional reforms necessary to achieve ecologically sustainable management of the jarrah forests.

\section{Biogeography of the jarrah forests}

The forested ecosystems of south-western Australia occur over an area of about 4.25 million hectares in three biogeographic regions: Swan Coastal Plain, Jarrah Forest and Warren (IBRA bioregions sensu Thackway and Cresswell 1994) (see Figure 1a for the bioregions and Figure $1 \mathrm{~b}$ for the extent of State forest within them). They include most of Western Australia's commercially important hardwood forests, including the major timber species jarrah as well as karri E. diversicolor; the latter occurs mainly in the Warren. Marri Corymbia calophylla, a less important timber tree, often co-occurs with jarrah or karri. In each of these bioregions, forests occur in a matrix of vegetation types reflecting an extraordinarily long and complex geological and climatic history. Jarrah exhibits a variety of growth forms and occurs in a range of community types throughout the region (WardellJohnson et al. 1997). Detailed accounts of the distribution, history, silviculture and ecology of the jarrah forests can be found in Abbott and Loneragan (1986), Dell and Malajczuk (1989), Shearer and Tippett (1989), Bradshaw et al. (1991) and Wardell-Johnson et al. (1997). The importance of the jarrah forests for timber production was emphasised by Rodger (1952, p.18):

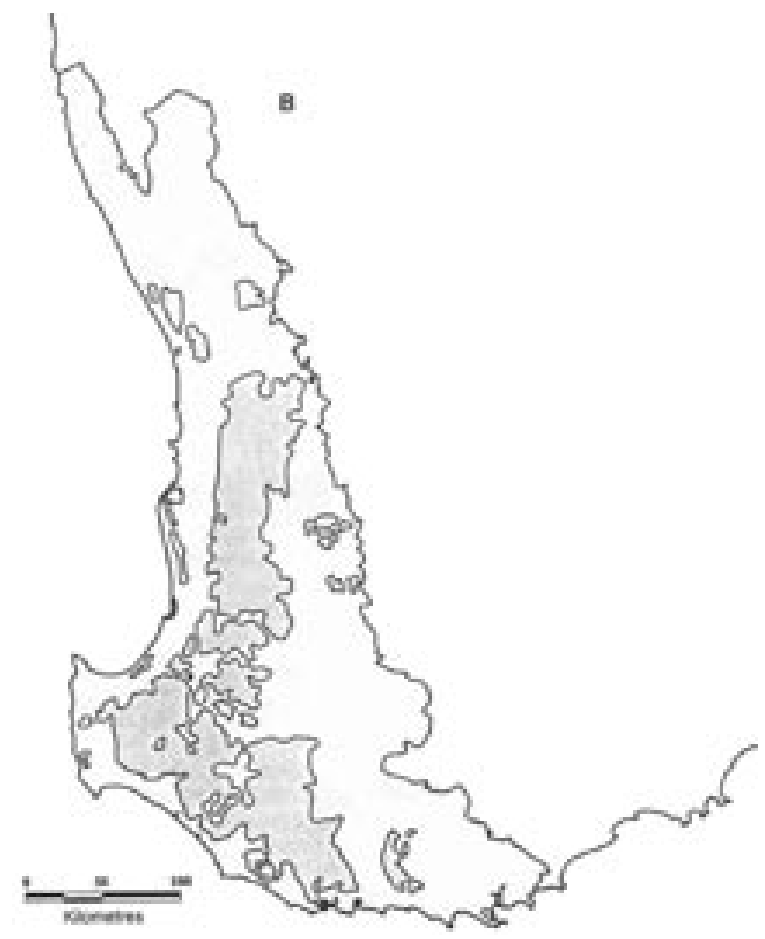

Figure I. (a) The IBRA bioregions in south-western Western Australia (after Thackway and Cresswell 1994).

(b) Distribution of State forest within the IBRA bioregions (after Calver and Dell 1998a). 
... the greater part of the volume available for cutting from State forests and other Crown lands over the next 60 to 90 years is in the jarrah forest, which constitutes the bulk of the forest area of the South-West. About one half of the jarrah forest is still virgin.

Logging and associated activities (e.g., road building, prescribed fire, and silvicultural operations) are the most extensive disturbances in State forest in south-western Australia. Moreover, extensive agricultural clearing has fragmented remaining native vegetation within and surrounding State forest. Other land uses include clearance for roads and powerlines and extensive mining for bauxite, coal, tin and mineral sands. Disturbances caused by urban or rural growth and encroachment, or by expanded recreational pursuits, may become as extensive in the future as logging has been in the past.

Compared to eucalypt forests in eastern Australia, the jarrah forest fauna has a lower species richness within several taxonomic groups including mammals and birds (Nichols and Muir 1989), freshwater fish and freshwater insects (Bunn and Davies 1990). This belies the significance of the jarrah forests for fauna conservation. The forested regions of the south-west are amongst the most important in Australia for the conservation of threatened mammals and birds (see Figures 1 and 2 of Maxwell et al. 1996 for mammals and p. 624 of Garnett and Crowley 2000 for birds) and recent morphometric studies indicate the biological uniqueness of some of these populations (e.g., Rhind et al. 2001). Reptile diversity in the jarrah forest is low (Nichols and Muir 1989), although despite some overlap the reptile community of the jarrah forest is distinct from that of the adjacent wheatbelt (Chapman and Dell 1985). Moreover, the Pretty Worm-lizard Aprasia pulchella, the Speckled Stone Gecko Diplodactylus polyophthalmus and the South-western Slider Lerista m. microtis are centred on the forest with some records on the adjacent coastal plains and there is one endemic, the Darling Range South-west Ctenotus Ctenotus delli (John Dell, Western Australian Department of Environmental Protection, pers. comm.). The amphibians include the endemic Geocrinia rosea complex of four allopatric species (Roberts et al. 1990, Wardell-Johnson and Roberts 1991) and the newly discovered (1994) genus Spicospina (Roberts et al. 1997). Other species, such as the Western Marsh Frog Helioporus barycragus and the Plains Frog $\mathrm{H}$. inomatus, are largely restricted to forest following destruction of suitable habitat elsewhere (John Dell, Western Australian Department of Environmental Protection, pers. comm.). The fish fauna is species poor but highly endemic (Morgan et al. 1998). Turning to the invertebrates, the freshwater insect fauna of running waters is not rich in species (Bunn and Davies 1990), but freshwater invertebrates of lakes and wetlands towards the coast have both high species richness and high endemism (Horwitz 1997). The species composition and distribution of the terrestrial invertebrate fauna is poorly studied, but recent work confirms a high invertebrate diversity on and under jarrah and marri trees (e.g., Abbott et al. 2001, Majer et al. 2002). Overall, recognition of these important fauna conservation values is essential in sustainable management of the jarrah forests.

\section{Measuring ecologically sustainable forest management}

\section{Defining sustainable development}

Sustainable development was originally defined as '... development which meets the needs of the present without compromising the ability of future generations to meet their own needs' (World Commission on Environment and Development 1987, quoted in Harris and Goodwin 2001, p. xxix). It is an evolving concept and variations on the theme include, but are not limited to, sustainable development (SD) (Calow 1998a) with its subsets of economic sustainability, environmental sustainability and social sustainability (Goodland 1995; Harris and Goodwin 2001). Ecologically sustainable development (ESD) (Good 1995, Deville and Turpin 1996, Maser 1999) and ecologically sustainable forest management (ESFM) (Ferguson 1996, Lindenmayer and Recher 1998, Lindenmayer et al. 2000) are nested within environmental sustainability. Diagrammatic representations of the interrelationships of the different subsets of sustainability are given in Charts 1 and 2 of Serageldin (1993), Figure 2.4 of Salwasser et al. (1993) and Figure 7.1 of van Dieren (1995).

The differing forms of sustainability share a concern for natural capital, which is the ...'stock of environmentally provided assets (such as soil, atmosphere, forests, water, wetlands) which provide a flow of useful goods or services. The flow of useful goods and services from natural capital can be renewable or nonrenewable, and marketed or nonmarketed' (van Dieren 1995, p. 100, see also the concept of 'critical natural capital' in Elkins et al. 2003). This is distinct from other kinds of capital reflecting human creations or human societies. According to van Dieren's (1995) overview, sustaining natural capital can take one of four forms:

- weak sustainability, which aims for the preservation of the sum of all forms of capital and assumes interchangeability amongst them. Thus exhaustion of a non-renewable resource (natural capital), would be acceptable if it was transformed into an equivalent amount of human-made capital,

- sensible sustainability, which places limits on the interchangeability of the different forms of capital, accepts that they are often complementary and recognizes that the total system will only function fully when all forms of capital are present at minimum levels,

- strong sustainability, which denies the full interchangeability of different types of capital and requires separate accounting for each type,

- and absurdly strong sustainability, which aims never to deplete anything. The 'absurd' arises because non-renewable resources could not be used under this approach, although the accompanying view that the harvest of renewable resources should always be within replacement is an ideal of 'wise-use' utilitarian approaches to the environment (e.g., Salwasser 1997). 
Van Dieren (1995) sees three strengths of adopting one of the strong sustainability approaches: explicit incorporation of social, economic and environmental considerations, a recognition of long time horizons in planning and decision making, and provision of a framework that allows business and development interests to discuss the environment.

ESFM includes all forest uses and ecological services including timber production (Boyce 1995, Ferguson 1996, van Bueren and Blom 1997, Turner and Lambert 1997, Calow 1998b) and thus sits comfortably within a sustainable development framework. Thus van Dieren (1995, p. 104) observed: 'A sawmill (human-made capital) is worthless without the complementary natural capital of a forest.' Furthermore, forestry as a profession has a strong tradition of managing forests for a sustainable yield of timber over long time horizons, including in Western Australia (e.g., Lane-Poole 1920, Kessell 1928, 1935). However, assessing whether or not ESFM is achieved is not simple. It involves consideration of the area and time over which sustainability applies, the properties or processes being sustained, identification of who will benefit and identification of who will meet any associated costs (Johnson 1993, Noss 1993, Calver et al. 1998). Here we limit discussion to area, time and properties to be assessed, excluding sociological and economic questions of costs and benefits (see Chindarsi 1997 for coverage of these issues).

\section{Choice of time and area scales}

The founding of Perth, the capital city of Western Australia, was marked by the felling of a jarrah tree (Mills 1989) so forest management issues could be considered as commencing with the initial establishment of the colony. However, significant regulation of forest management was not implemented until the Forests Act of 1918. Therefore our main focus is on the period 1920 - 2000, embracing management under the Forests Department from 1918 - 1985 and the Department of Conservation and Land Management (created by merging the Forests Department with the National Parks Authority and parts of the Department of Fisheries and Wildlife) after 1985. The appropriate main area to consider would be State forest, but many sources give figures or ascribe comments to the broader category of Crown Land, which includes both State forest and other land tenures for which sustainable management is not necessarily a goal. In some cases, comments apply to the south-west of Western Australia as a while. Accordingly, we indicate when comments or figures apply to State forest specifically or to the broader category of Crown Land.

\section{Choice of properties and processes to assess}

Quantitative measurement of the achievement of ESFM is a recent management concern, growing in importance in jarrah forest management after 1965 (Carron 1985, Burrows et al. 1995, Dargavel 1995). For example, explicit consideration of biodiversity conservation, forest reserves, mining, recreation and water catchment protection were first reflected in a Forestry Department Working Plan in 1972 (Forests Department 1977). Therefore full quantitative assessment of ESFM is unsuitable for assessing the history of jarrah forest management because the necessary data are available for only a limited period and all ESFM values applied over only a short period of forest management in Western Australia. The sustainability of the timber cut is an alternative because this was a goal over much of the period. It also has the advantage of limiting the range of data required and it is an important component of ESFM.

Sustained yield is a possible measure of the sustainability of the timber cut. Helms (1998, p. 181) offers two definitions:

1. The yield that a forest can produce continuously at a given intensity of management - note sustained yield management implies continuous production planned as to achieve at the earliest practical time a balance between increment and cutting.

2. The achievement and maintenance in perpetuity of a high-level annual or regular periodic output of the various renewable resources without impairment of the productivity of the land.

Ferguson et al. (1997), Turner (1998) and Ferguson et al. (2001a) documented the steps in calculating sustained yield of jarrah. They include defining the net areas available for logging, estimating the standing volume for these areas, projecting future growth or volume and then modelling the potential woodflows to determine sustained yield. The solution also depends on the quality of the product sought. For example, quantities of different grades of sawlogs and other products fluctuate over time depending on the type of forest being logged, the silvicultural practices and market conditions. If sustained yield is achieved, then the forest should be nearer ESFM than if it is exceeded.

Early Western Australian foresters accepted the concept of sustained yield (e.g., Lane Poole 1920a,b; Kessell 1935) and by the early 1980s it was integrated into multiple use management (Beggs 1982; Bradshaw et al. 1991). It is implicit in the Commonwealth's acceptance of the Montreal criteria (van Bueren and Blom 1997). However, the detailed background data for sustained yield calculations do not exist over the period 1920 - 2000. For example:

It is quite impossible to estimate the duration of supplies, owing to the lack of full information regarding the present stocking and the rate of growth. Lane Poole (1920, p. 31)

This assessment dealt with mature and semi-mature timber only and no estimate of the volume of the immature growing stock is possible at present. There is a serious deficiency in the older age classes from the small pole stage onwards. A start has been made to carry out more intensive assessments as part of regional survey work on modern lines and before the next statement is prepared much more complete data should be available. Kessell (1938, p.6)

Every effort be made in time for the next revision of the working plans in 1954 to determine as accurately as practicable in the time the maximum sustained yield possible from the forests of the South-West. Rodger (1952, p.18)

Furthermore, it has been claimed that the conditions necessary for calculation of a sustained yield were not present over much of the period, as noted by Forests Department (1977, p.4): 
There can be no simple equation between gross forest increment and annual cut as envisaged in the classical concept of sustained yield, until the forest contains a complete range of age classes in units of equal area of productivity. Desirably markets for the full range of produce coming forward annually should also be available. These conditions do not apply in Western Australia because of the intensity and distribution of previous cutting as well as other factors affecting the growth rates in the hardwood forest and because the plantation estate is still being developed.

Although Vanclay (1996) provides an approach for calculating sustained yields in uneven aged stands, it seems likely that the data to attempt such calculations in Western Australia were lacking until recent times when sustainable yield calculations became integral in determining the level of logging (e.g., Meagher et al. 1993, Ferguson et al. 1997, 2001a,b).

An alternative could be to use either the allowable cut, which represents the total sawlog volume allowed from State forest and Crown lands under Forestry Department Working Plans, or the permissible cut, which referred to the total sawlog volume permitted for individual mills under Forestry Department Working Plans (Rodger 1952). While these figures are more readily available, a significant problem is that for many years they were based on criteria other than a sustainable yield of timber.

The allowable cut is determined on management rather than on silvicultural criteria. The main factors which must be taken into account are existing levels of demand, types of produce required, and the period required to accumulate future forest capital in the most desirable range of size classes. Forests Department of Western Australia (1977, p.5).

Consequences of this included that the '... permissible cut at any time was never likely to be achieved' (Rodger 1952, p. 17) but that nevertheless the permissible cut for many mills exceeded that which could be sustained for a long time (Rodger 1952, p. 19). Thus there is no demonstrable relationship between either allowable or permissible cut and a sustainable timber yield from either forests at a landscape scale or at the level of individual mills. This makes allowable and permissible cuts unsatisfactory statistics for estimating sustainability.

A further possibility is to apply the concepts of 'forest capital' (the total marketable timber) and 'forest interest' (the growth increment on that capital), which persisted in literature of the Forests Department for decades (e.g., Lane Poole 1921, Forests Department 1971). Under this approach, responsible management should keep the volume of timber cut within the growth increment, thereby conserving the forest capital. The analogy of forest capital antedates the concept of natural capital as used in sustainable development (e.g., van Dieren 1995, Elkins et al. 2003) by several decades. For example:

The total increment for the whole of the jarrah forests in their present uncared for condition may be estimated at 270,000 loads a year. This is the amount we should be cutting, instead of which we are cutting 806,000 loads; or, in other words, we are going to leeward by over half a million loads a year. Lane Poole (1920c, p. 1)

Furthermore, careful choice of areas to cut and silvicultural approaches to felling would also enhance the rate and quality of regrowth, leading to an improvement in increment and an increase in the annual volume cut (Lane Poole 1920a,c). This approach has the great advantage of simplifying assessments of the sustainability of forest management in any year, by invoking a comparison of increment and harvest without consideration of the many variables involved in calculating sustained yield. Furthermore, the analogy of capital and interest anticipates the use of natural capital in sustainable development discussions. Its disadvantages are that figures for increment may be unavailable or questionable estimates (e.g., Rodger 1952) and they do not consider the valid possibility that increments may be exceeded for some years in the interests of altering the structure of forest stands for longer-term productivity gains (see extensive discussions in Meagher et al. 1993).

On balance, a full assessment of ESFM over the history of Western Australian forest management is inappropriate because of lack of available data and because many of its goals were not integrated into management until the 1970s. While sustainable yield was accepted as an important goal following the establishment of the Forests Department in 1918, the problems inherent in calculating it until recent years preclude its use in assessing the sustainability of past jarrah forest management. Data on allowable cuts are more readily available, but they were never intended as specific indicators of the sustainability of logging. Although we present some of these data, we base our primary assessment of the sustainability of jarrah forest logging on comparisons of timber volumes cut compared to contemporary estimates of the increment of the forests (which we use as a sustainability surrogate). While the increment values are often only estimates, they do represent a yardstick against which contemporary managers could and did compare their practice. To allow for the possibility that logging may exceed increment as a deliberate policy to modify stand structure for a time, we also consider extensive qualitative commentary by forestry professionals on the appropriateness of contemporary management decisions.

\section{Has Western Australian forest management sustained timber production?}

\section{History of Western Australian forest management}

Logging of open-forest communities dominated by jarrah began soon after European settlement in 1829 and most areas of jarrah forest have at some stage been logged (Havel 1989a,b; Mills 1989). Important events in the development of a timber industry can be grouped into three periods: almost unimpeded exploitation, intensifying between 1880 and the promulgation of the Forests Act in 1918; expansion of State forest, silvicultural reconstruction, fire exclusion and emphasis on timber production and water catchment protection from then until the mid 1960s; and a 
contemporary phase of multiple-use values in management, replacement of fire exclusion with prescribed burning and intensive utilization of forest products (Carron 1985; Burrows et al. 1995; Dargavel 1995). While Robertson (1956) and Nunn (1957) recognize three eras in the period before 1918, the substantial lack of regulation throughout that time means that considering them as one period is appropriate for this discussion.

In the period to 1918, the dominant forces were the desire to clear land for agriculture and to cut timber for both domestic consumption and the export trade (Lane Poole 1920b; Mills 1989). Cutting by private individuals and larger concerns was not regulated strongly and citizens desiring a long-term, sustainable industry were concerned at the waste (e.g., Lane Poole 1920a). Furthermore, the forest overstorey was opened, and piles of logging slash abandoned on the forest floor increased fuel loads. These actions, coupled with the use of steam-driven equipment and a general carelessness with fire, led to fires of unprecedented intensity and wide geographic spread (Wallace 1965; Forests Department 1971; McCaw and Burrows 1989; Burrows et al. 1995). Early photographic records contrast the structure of the unexploited forest, characterised by uneven stands containing many large, old trees over open understoreys, with some of the worst devastation arising from both unrestricted logging and associated wildfire (Figures 2-3).

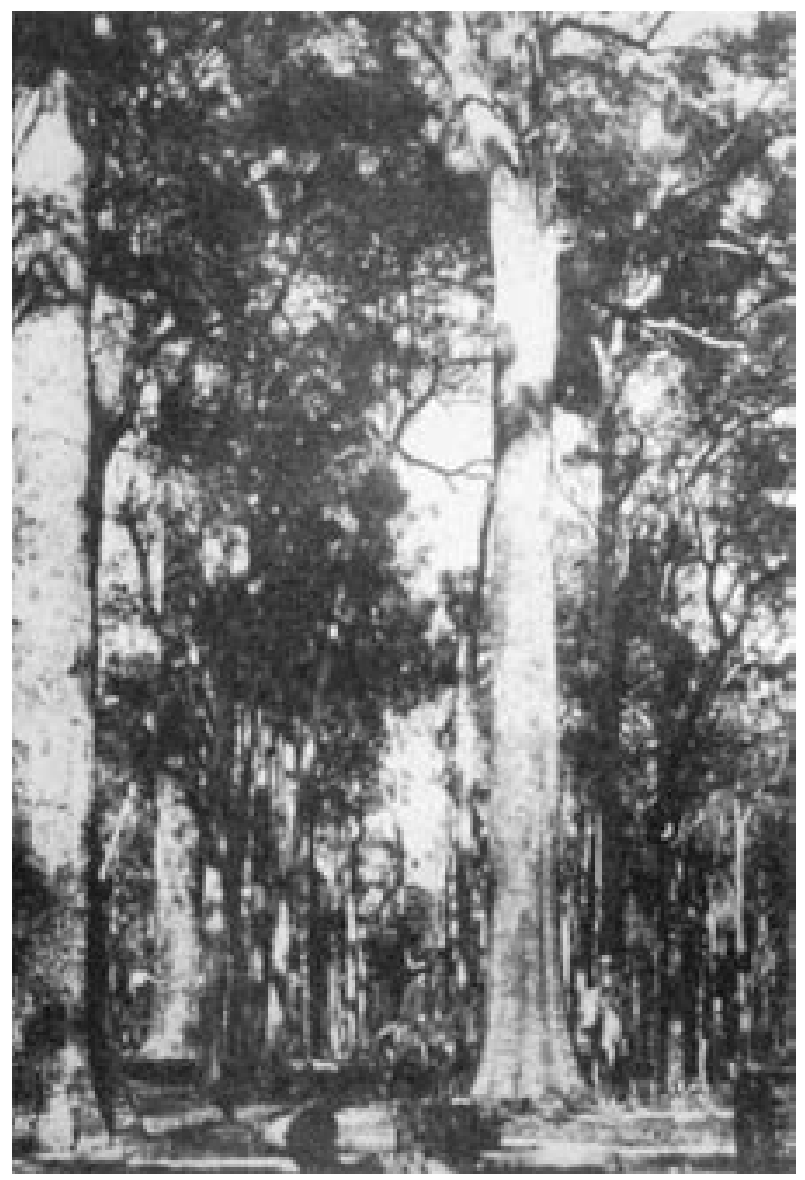

Figure 2. Jarrah forest near Jarrahdale, c. 1895. The riders in the foreground give a sense of scale (reproduced from Lane Poole 1920b, with permission of the Department of Conservation and Land Management).
Conflict also arose over nature conservation. As early as 1894 the Australian Association for the Advancement of Science lobbied successfully for the creation of the 64000 ha South Dandalup reserve in prime jarrah forest near where Pinjarra stands today. However, it was not properly vested and in 1911 was reclassified for timber and agricultural purposes following opposition from timber interests (Rundle 1996). Thus by the early twentieth century persistent strands of land-use conflict involving agriculture, forest management and nature conservation were established in the south-west.

The Forests Act of 1918 sought a resolution of these issues and began the second broad era of Western Australian forest management. Amongst other reforms the Forests Act foreshadowed the vesting of large areas of the south-west as State forest dedicated to the sustainable production of timber in perpetuity and established the Forests Department to manage this estate. The new department sought a sustainable timber industry in State forest as rapidly as possible, using the concept that the cut should remain within the increment as an index of responsible management (e.g., Lane Poole 1921, Forests Department 1971).

Central to policy was increasing the area of State forest, reducing the rate of logging to within the growth increment of the forest, extensive reforestation on cutover areas, removal of over-mature, senescent trees and

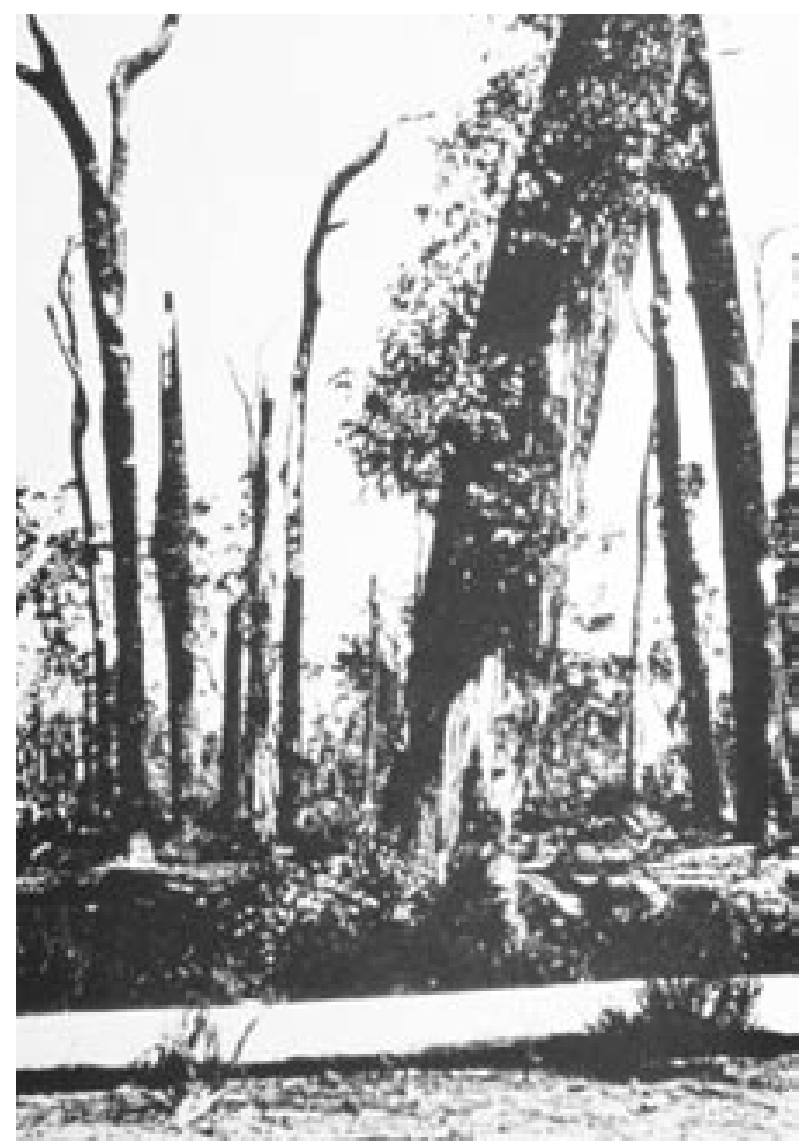

Figure 3. Photographic evidence of 'The remains of a jarrah forest devastated by fire from the massive accumulation of debris following early logging' (reproduced from Forests Department 1971, with permission of the Department of Conservation and Land Management). 
trees of non-commercial species, extensive fire protection for regrowth stands and conversion of large areas of forest to even-aged stands to facilitate the management of logging rotations (Lane Poole 1920a; Kessell 1928, 1935). However, regulating the cut proved difficult in the face of such crises as the Great Depression (Kessell 1932, 1935), the Second World War and post-war reconstruction (Stoate 1947, 1953).

Furthermore, the rapid spread and intensification of dieback disease caused by the introduced pathogen Phytophthora cinnamomi followed a major road-building program after the great depression and again after the Second World War. In part, spread was hastened by the use of gravel from dieback 'graveyard' areas of jarrah forest for road building programs to establish a network throughout publicly managed land (G.E. St.J. Hardy, Murdoch University, pers. comm.). Limited data collected during the 1960s suggested that substantial losses in timber production might follow dieback infestation, but more detailed measurements are lacking (Davison and Shearer 1989).

There was also a gradual realization that the most productive forest areas were not as extensive as believed, nor was regrowth as rapid in jarrah as had been hoped (Kessell 1922; Pickering 1922; Rodger 1952). Establishing sound silviculture in the face of the damage that the Forests Department inherited also proved difficult (Kessell, in the foreword to Stoate 1926). The solution, expounded in the Royal Commission of 1952 and the Jarrah, Karri and Wandoo Working Plan of 1956, involved: extending logging into the virgin southern forests where large volumes of timber existed in the uncut stands, (ii) encouraging private landholders to supply as much of the required timber as possible to ease production pressures on State forest, (iii) increasing areas of softwood plantations, (iv) improving the health and hence the productivity of jarrah forest, and (v) increasing the area of State forest. Logging methods, forest management procedures and silvicultural systems evolved throughout this period, especially in forests including jarrah (Bradshaw and Lush 1981; Abbott and Loneragan 1986; Stoneman 1986; Stoneman et al. 1989; Havel 1989a; Bradshaw 1991; Breidahl and Hewett 1995).

Problems with fire prevention culminating in massive and destructive fires in the south-west in the 1960s began a third management era, characterized by an intensification of broad-scale prescribed burning, mainly in spring, to reduce the fire risk (see Harris and Wallace 1959 and Wallace 1965 for development of the prescribed burning policy). Policy sought to achieve regular burning of about $70 \%$ of the most productive jarrah forest at around five to seven year intervals (Wardell-Johnson and Nichols 1991). Gill et al. (1997) estimated that the fire cycle decreased from 16 years in 1951/52 to five years in 1968/69. It then increased to about 14 years in 1995/96. The area of prescribed burning has continued to decrease since 1995/96 (Burrows and Wardell-Johnson 2003). Fire management is an integral part of silvicultural practice associated with logging in jarrah forests (CALM 1989). Logged areas and those immediately surrounding them are burned before and after logging. This allows ease of access, protects regrowth from subsequent regeneration or 'tops disposal' burns and encourages regeneration (Underwood and Christensen 1981). Areas of regeneration are then protected from fire until they are old enough to remain economically undamaged (see Wardell-Johnson 2000) following a mild prescribed burn (i.e., at a height of 5-6 m for jarrah; Peet and McCormick 1971).

Once the fungus responsible for dieback-disease was identified in the 1960s (Podger 1972), considerable attention was directed towards associated forest policy and management activities (e.g., chapters 6 and 7 of Shearer and Tippett 1989). This included the 'quarantining' of some areas of State forest until the presence (or absence) of Phytophthora could be confirmed; the clearance of some areas of State forest of reduced productivity in the northern part of the Blackwood Plateau for the establishment of pine plantations; and the management of mosaics of infected and apparently dieback-free areas of State forest.

This period also saw a growing realization of the value of the forests for many purposes other than timber production, leading to multiple-use management policies recognizing a wide-range of forest uses and values. For example, the 1987 working plan listed 21 important management goals for State forest, of which only five related to wood products (Forests Department 1987). Various interventions by government in the interests of environmental protection also occurred, such as the establishment of a national park in the Shannon River Basin (Rundle 1996) and the end of the conversion of areas of the Blackwood plateau to pine plantation. However, many critics of forest policy were unappeased by multiple-use management, especially after the establishment of a wood-chipping industry in the southern forests in the 1970s (e.g., Conacher 1983 and included references, Chapter 17 of Mills 1986) and commencement of large-scale mining of the jarrah forests for bauxite at the same time. In the late 1990s, the State Government of Western Australia and the Commonwealth Government of Australia attempted to provide security for both forest reserves and resource availability through a Regional Forests Agreement (RFA), to balance competing interests for the next 20 years. There has been further controversy over this approach, with some authors providing a positive assessment of its overall effectiveness, e.g. Davey et al. (1997), and others, a more negative assessment (e.g. Dargavel 1998). This controversy is also reflected for Western Australia in particular (see Davey et al. 2002 cf Horwitz and Calver 1998, Buchy and Hoverman 2000). In the 2001 state elections, the ALP secured government with a policy of ending logging in old-growth forest in Western Australia.

\section{Assessing adherence to sustainability}

Given the emphasis on protecting and developing forest resources for timber production from early in the history of Western Australian forest management, it is appropriate to assess the success of past management in achieving these goals. We chose to do so through a comparison of increments versus the timber cut (both sawlog volume and the volume 
Table I. Comparisons of volumes of both sawlogs and hewn and milled sleepers in the round (the 'cut') and contemporary estimates of either the annual increment or sustained yield for Western Australian hardwood forests 1920 - 2000. See notes to indicate the land tenure covered by the figures. Volumes given in $\mathrm{m}^{3}$ are either taken directly from the source, or converted from Imperial measurements using the conversion factors:

l load $=1.416 \mathrm{~m}^{3} \quad \mid \mathrm{ft}^{3}=0.02832 \mathrm{~m}^{3}$

\begin{tabular}{|c|c|c|c|c|c|}
\hline Year & Tree species & Cut $\left(\mathrm{m}^{3}\right)$ & Increment $\left(\mathrm{m}^{3}\right)$ & Disparity $\left(\mathrm{m}^{3}\right)$ & Reference \\
\hline 1919 & All native species & 569549 a & $188065^{a}$ & $-38 \mid 484^{a}$ & Lane Poole (I920a) \\
\hline 1919 & All native species & $185377^{b}$ & $188065^{b}$ & $+2688^{b}$ & Lane Poole (I920a) \\
\hline 1922 & Jarrah & $564972^{a}$ & $176554^{a}$ & $-388418^{a}$ & Pickering (1922) \\
\hline 1927 & All native species & $2215870^{a}$ & $165389^{a}$ & $-2050481^{a}$ & Kessell (1928) \\
\hline 1927 & All native species & I $028270^{b}$ & $165389^{b}$ & $-\left.86288\right|^{b}$ & Kessell (1928) \\
\hline 1927 & All native species & - & - & $-329096^{c}$ & Kessell (1928) \\
\hline 1934 & All native species & $781433^{a}$ & $180370^{a}$ & $-601064^{a}$ & Kessell (1935) \\
\hline 1934 & All native species & $388635^{b}$ & $180370^{b}$ & $-208265^{b}$ & Kessell (1935) \\
\hline 1939 & All native species & $830484^{d}$ & $836856^{d}$ & $+6372^{d}$ & Stoate (1947) \\
\hline 1961 & Jarrah & $725457^{c}$ & $990000^{c}$ & $+264543^{c}$ & Hansard (I974a) \\
\hline 1966 & Jarrah & $821679^{c}$ & $800000^{c}$ & $-21679 c$ & Hansard (1974a) \\
\hline $197 \mid$ & Jarrah & $779597^{c}$ & $644000 v$ & $-135597^{c}$ & Hansard (1974a) \\
\hline 1974 & Jarrah & $657400^{c}$ & $355000^{c}$ & $-302400^{c}$ & Hansard (1974a) \\
\hline 1993 & Jarrah & $379550 c$, & $\begin{array}{l}250000^{c, f} \\
300000\end{array}$ & $\begin{array}{l}-129550^{c} \\
-79550\end{array}$ & Meagher et al. (1993) \\
\hline
\end{tabular}

\section{Notes}

a. These figures include both domestic consumption and the export trade and include timber cut on both private land and Crown Land.

b. These figures relate to domestic consumption only and include timber cut on both private land and Crown Land.

c. These figures are for State forest only.

d. This figure is for Crown Land only

e. Figures for the cut are taken from CALM 1993

$\mathrm{f}$. These figures are estimates of sustained yield, not increments. In differing places the Meagher report uses either $250000 \mathrm{~m}^{3}$ or $300000 \mathrm{~m}^{3}$ as a conservative estimate of the sustainable yield of jarrah sawlogs.

hewn or sawn for railway sleepers), regarding this as an index of sustainability. Of course, techniques for estimating the growth increments of forests are refined continually, so the estimate at any time may be wrong when judged with hindsight (compare, for example the fluctuations in estimates of the increment rates for the jarrah forests before 1945 shown in Table 1). Similarly, comparisons between years are inappropriate because of differences in inventory and logging techniques and standards. Different areas of forest were involved, the tenure and purpose of forested areas altered, product specifications changed and the age composition of forests at different times varied. However, paired comparisons of increment against logging volumes in a given year are robust against these differences over time and valid in revealing whether or not a sustainable policy was likely to be achieved by the standards of that time. Examination of Forestry Department bulletins and annual reports and Hansard records of debate in the Western Australian parliament gives such paired figures for the years 1920, 1922, 1927, 1934, 1939, 1961, 1966, 1971 and 1974. We also include a figure for a sustained yield calculation in 1993. There are also qualitative indications of trends in other years and explanations for the policies pursued. Oral histories based on interviews with early Western Australian foresters offer further insights.
After the Forests Act of 1918 the area of dedicated State forest grew rapidly and by 1930 already approximated $60 \%$ of its extent in the year 2000 (Figure 4). From the beginning, the Forests Department strove to achieve a sustained timber yield on State forest and other Crown lands, often describing this as confining logging within the annual increment of the forests (e.g., Lane Poole 1920a; Stoate 1926; Kessell 1928). Early figures, based on the situation across all land tenures in the south-west and all native hardwood felled, were daunting (Table 1). For example, in 1927, native hardwood logging for domestic consumption alone exceeded the estimated increment of the forests by $862881 \mathrm{~m}^{3}$ and the figures worsened to 2050 $481 \mathrm{~m}^{3}$ when the large export trade was included. Closing mills immediately was logical but politically unacceptable (Lane Poole 1920a). Instead, the 1929 Working Plan for jarrah aimed at a gradual reduction to reach a sustained yield within 10 years (Kessell 1935). Logging did decline in the late 1920s, following the collapse of domestic and export demand in the Great Depression of 1929 (Figure 5 , see also Stoate 1947 , p. 4). It recovered by the mid1930s when it was still above contemporary estimates of the growth increment of the forests (Table 1), but optimism was high as Kessell (1935, p.13) stated that 'The forestry position in Western Australia has improved 


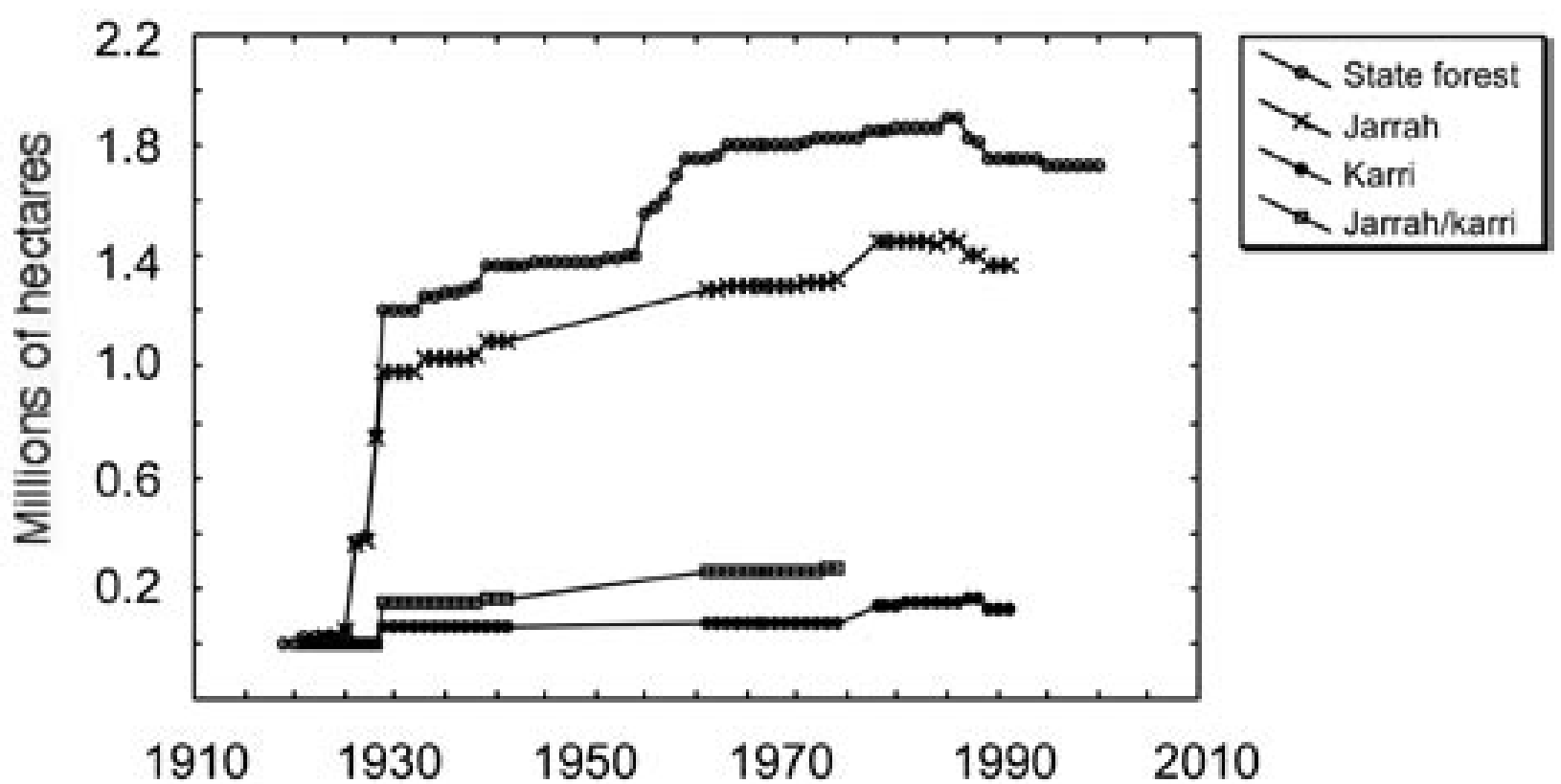

Figure 4. The total area of State forest, 1920 - 2000. However, component data are unavailable for all years and the system for classifying forest types is inconsistent over time, so the species data are only generalizations. Data are taken from annual reports of the Forests Department and the Department of Conservation and Land Management.

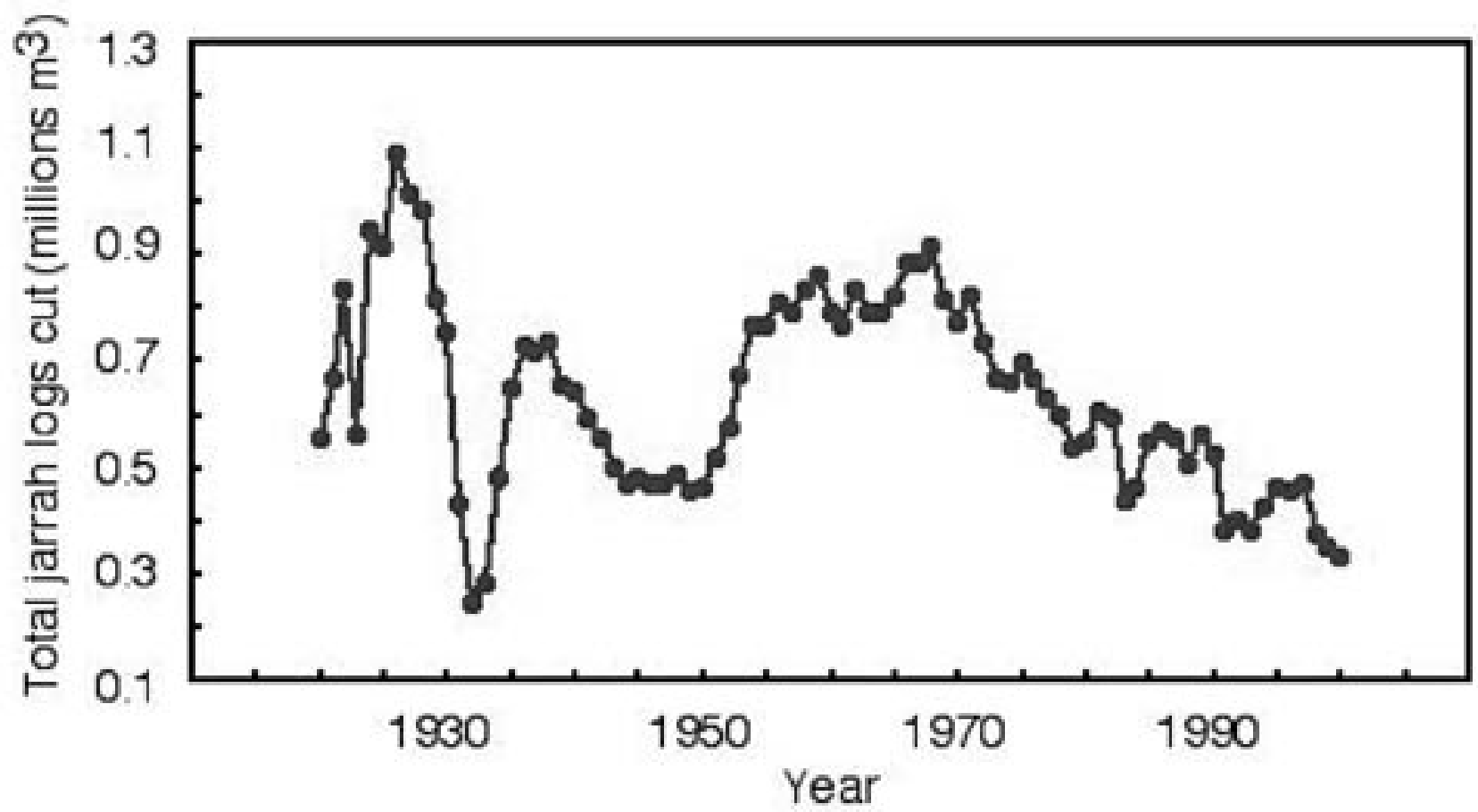

Figure 5. The volume of jarrah sawlogs and jarrah cut for sleeper hewing cut from Crown Lands, 1920 - 2000. Data are taken from annual reports of the Forests Department and the Department of Conservation and Land Management.

materially since the 1928 Conference', a view endorsed by Mills (1986, 2002). Indeed, Stoate's (1947) figures for 1939 indicated that logging and increment had reached a balance on Crown Lands at that time (Table 1), although he foreshadowed a possible need to reduce logging volumes in the 1950s. Logging fell again during Word War II, but rose rapidly during post-war reconstruction (Figure 5, see also Stoate 1947, p. 4).

Although we were unable to locate figures for the growth increment of the forest between 1939 and 1961, qualitative comments suggest that the post-war boom may have disrupted the balance between cutting and increment achieved just before the Second World War. Controversy over the sustainability of cutting appeared in annual reports of the Forests Department and the report of the Royal Commission of 1952:

The position must be faced that mills without $\log$ supplies must eventually close down, and the earlier the permissible cut is reduced to one which can be sustained over a long period, the less will be the dislocation in the timber industry. Rodger (1952, p. 19) 
Demands for increased timber supplies by builders and sawmillers, if acceded to, can do much in a short period to nullify a state of equilibrium and balance between the forest, the timber industry and timber users which may have taken years to achieve. These are matters which it is believed deserve the serious consideration of the Government. (Rodger 1952, p. 39)

This year's production represents a far greater output than the forests of the State can maintain, and moreover, the rate of cut is still increasing. Stoate (1953, p. 1)

The record total production of $18,345,428$ cubic feet [519,542 cubic metres] of sawn and hewn timber involving the cutting of over one million loads [1.416 million cubic metres] of logs in the round this year 1953-54 is thought to be nearing the limit of State Forest sustained output. At present about 26 per cent. of this comes from Private Property which has only a limited life, and about 21 per cent. of the total is exported. Harris (1954, p. 1)

Moreover, the Royal Commission of 1952 recommended steps to improve the health of the jarrah forest, meaning an increase in productivity to meet large timber demands (Rodger 1952). A more optimistic view was taken by 1955 , based on increased planting of exotic softwoods and plans for increased productivity (Harris 1955, Forests Department 1956) and a belief that current cutting was below the 'sustained yield potential' of the State forests (Forests Department 1956, p. 22). Indeed, Mills (1986, p. 185) noted that during the 1950s ' ... the Western Australian forest was still accepted by most as more or less inexhaustible.'

The optimism was short-lived. Questioning in the Western Australian Legislative Assembly in 1974 revealed on-going overcutting of jarrah during the 1960s and 1970s (Table 1), which the Minister for Forests claimed was needed for commercial reasons (Hansard 1974a,b). Later questioning showed clearly that the overcutting in both the jarrah forests and the adjoining karri forests was not otherwise on the public record:

Mr A.R. TONKIN, to the Minister for Forests:

(1) Further to question 19 asked on $17^{\text {th }}$ October, has the level of overcutting in the State's hardwood forests ever been reported in the annual reports made by the Conservator of Forests since 1960?

(2) If so, in which years and on which pages of these annual reports?

(3) Did the environmental impact statement prepared by the Forests Department concerning the Manjimup woodchip project state the degree of overcutting of the State's karri forest?

(4) If so, on what page?

Mr O'CONNOR (for MR RIDGE) replied:

(1) No.

(2) Answered by (1).

(3) No.

(4) Answered by (3). Hansard (1974c)
Table 2. Comparisons of the permissible hardwood cut and contemporary estimates of the annual increment for Western Australian hardwood forests 1965 - 1974. Data from Hansard (1974a,b). Note that the permissible hardwood cut includes small volumes of tuart, wandoo, mallet Eucalyptus astringens and blackbutt E. patens.

\begin{tabular}{|c|c|c|}
\hline Year & $\begin{array}{l}\text { Permissible cut for } \\
\text { hardwood } \mathrm{m}^{3}\end{array}$ & $\begin{array}{l}\text { Then estimated jarrah } \\
\text { increment } \mathrm{m}^{3}\end{array}$ \\
\hline 1965 & 1226510 & \\
\hline 1966 & 1238915 & 800000 \\
\hline 1967 & 1241237 & \\
\hline 1968 & | 178593 & \\
\hline 1969 & I 204733 & \\
\hline 1970 & $1083 \quad 86$ & \\
\hline 1971 & $106862 \mid$ & 644000 \\
\hline 1972 & I 1 1675| & \\
\hline 1973 & I 106995 & \\
\hline 1974 & 1091290 & \\
\hline
\end{tabular}

Furthermore, the declines in the estimates of the annual increment in the jarrah forests between 1961 and 1974 (Table 1) were not matched by substantial declines in the permissible cut of hardwood over the same period (Table 2). These trends were not restricted to Western Australia:

A major cause of the movement to softwood production has been a general pattern of overcutting of the native forests, particularly in the 1960s and 1970s, in most states. The inevitable consequence is an impending trough in the future supply of hardwood sawlogs because most of the unreserved old growth will be cut out well before significant numbers of regrowth sawlogs are old enough to be harvested. Resource Assessment Commission (1991, P xlviii).

Awareness of the consequences of overcutting was apparent in the 1970s and 1980s. Mills (1986, p.239) noted:

Now the hardwood men had to accept that the forests were overcut and that cutting restrictions would increase. For some time the Forests Department had indicated the need to reduce the total volume of jarrah and karri sawlogs removed from the forest, with the intention of gradually reducing the cut to a level that the forest could sustain, while regeneration programmes were developed. The reductions were to coincide with an increase in softwood milling so that by the year 2000 a much reduced volume of hardwood would be cut. The planned reduction was from 990000 cubic metres in 1977 to 315000 cubic metres in 2010.

This view was also pushed politically, as revealed in the concerns of Conservator of Forests McNamara in a discussion paper presented to the WA Premier and the Minister for Forests:

It can take 100 years for karri and 250 years for jarrah to grow to mature stands. These growth rates would be acceptable if the area of forest was large enough. Unfortunately, past land use policies in Western Australia did not always consider forest conservation 
and the remaining forest area is inadequate. Current rates of cutting in the original forest cannot be sustained until a sufficient proportion of regrowth stands reach millable size. Cutting must, therefore, be progressively reduced for a period of $60-70$ years. McNamara (1984, p. 10).

In the 1970s Labor politician David Evans, the member for the electorate of Warren in the heart of timber country, echoed this view:

The forests were being overcut. They were being logged faster than the rate of regrowth. The industry has to consider whether the rate of cut should be reduced significantly now - which will mean more years of cutting at reduced level - or continuing at present rates with a drastic reduction in the future. Evans, cited in Mills (1986, p. 233).

However, the heightened awareness did not lead to a marked change in policy. After considering a range of scenarios, the Meagher report of 1993 recommended a further period of overcutting of jarrah:

... somewhere close to 250000 cubic metres/year of [jarrah] sawlogs would be sustainable in perpetuity. Meagher et al. (1993, p. 24)

However a harvest close to $450000 \mathrm{~m}^{3} /$ year for 10 years will not irrevocably damage the long-term yield even if the conservative $300000 \mathrm{~m}^{3} /$ year is subsequently proven to be more appropriate. Meagher et al. (1993, p. 27)

The report justified the overcutting on the basis of commercial and social reasons, presenting modelling analyses showing that the overcutting would lead to only a slight reduction in long-term timber yields.

Overall, there is no simple, quantitative answer to the question of whether or not this history of logging in the jarrah forests has been sustainable in terms of timber output because of the severe limitations to the available data. On one hand, Underwood (1983) provided a concise overview of arguments in favour of concluding that management of the south-west forests of Western Australia since the Forests Act of 1918 is consistent with sustainable outcomes. He highlighted the initial struggle to establish State forest in the face of pressure for agricultural clearing and the inevitable, protracted period of overcutting needed to convert virgin forest into a series of even-aged stands suited to sustained yield management. He also pointed out that vagaries of supply, demand and trade may warrant temporary deviation from sustained yield practices, or that natural disaster, social upheaval or urgent need for revenue may dictate short term overcutting. Under this view, forest management has striven for the ideal of sustainability within an unpredictable social and political context, sometimes directing cutting to land tenures other than State forest to shield State forest from overcutting (e.g., Forests Department 1956). Meagher et al. (1993) made similar arguments before recommending a level of jarrah cut reinforced by sustainable yield calculations that were audited independently. It is also true that periods of grave concern regarding the volume of timber cut have been followed by returned optimism after management adjustments (e.g., contrast Kessell 1928 and Kessell 1935, Stoate 1953 and Harris 1955) and that some forest historians have taken a generally positive view of the longterm sustainability of policy (e.g., Robertson 1956, Nunn 1957, Mills 1986). Furthermore, independent assessments over the last decade have endorsed the procedures now used to calculate sustainable yields in the jarrah forests (Meagher et al. 1993, Ferguson et al. 1997, 2001a,b, Turner 1998, Turner et al. 1999) and praised both the Forests Act of 1918 and its implementation (Rodger 1952). Abbott and Christensen $(1994,1996)$ and Abbott and Whitford (2002) extend these views, arguing that forest management has contributed not only to an on-going supply of timber but to wildlife conservation as well.

We disagree. While we accept that a period of overcutting may be balanced by a period of undercutting, our use of paired comparisons of increment against timber cut indicate that the jarrah forests were overcut substantially for much of the history of State forest management in Western Australia and that this followed over half a century of virtually unrestricted and wasteful logging. Admittedly, overcutting might be justified in terms of modification of virgin forest to even-aged stands most suitable for sustained yield management. It is also irrelevant if the aim is never to manage the timber sustainably, as in the case of Crown Land that is to be cleared before release for agricultural development (see particularly Nunn 1957, p. 7). However, this argument is inconsistent with the numerous cases up to the 1950s of professional disquiet with the volume of the cut. Political questioning followed in the 1960s and 1970s and a judgement of overcutting during these decades was supported by a range of sources including the independent Resource Assessment Commission inquiry (RAC 1991, 1992), Forests Department submissions to the WA Government (McNamara 1984) and the historical assessment of Mills (1986, especially pp. 227, 233 and 239). Over much of the period, sustainability remained a goal to be met up to a decade into the future (e.g., Kessell 1935, Meagher et al. 1993). It is this sustained overexploitation that concerns us. Furthermore, recent independent endorsements of the methods used to calculate sustainable yield figures for the jarrah forests apply to the methods themselves, not necessarily to the management choices made in the light of them. On balance, we believe that there was a prolonged history of overcutting in the jarrah forests and that this degree of exploitation substantially changed their structure, reduced the level of potentially sustainable logging and altered fauna conservation values.

We do not believe that this state of affairs can be blamed on the forest management profession in Western Australia. There is abundant evidence of professionals' warning against overcutting and the political pressures that overrode them. Disputes with government over forest management led Lane Poole to resign as Conservator of Forests in 1921, while Stoate was not renewed as Conservator in 1953 despite protest (Mills 1986), the same year in which he expressed concern regarding overcutting in an annual report (Stoate 1953). 'Dick' Perry, a Western Australian forester whose career began 
in 1917, expressed the position clearly:

We made determined efforts over a great many years to get the karri and jarrah on a sustained yield basis and as far as I am aware, I don't think we ever succeeded. It was political. They wouldn't shut down sawmills and little towns which became very necessary if you were going to work on a sustained yield basis. It certainly wasn't the foresters (sic) fault. They wouldn't make the tough decisions.

... As foresters, we were all aware of it, or I think most of us were aware of it anyway. But I don't think it really upset us emotionally or anything like that. We tried our best to tell governments what to do, and how to do it, but that's all we could do, by law. No, it was a fact of life and there was nothing we could do about it.' Douglas 'Dick' Perry, quoted in Borschmann (1999, p. 188)

Furthermore, we find it significant that there are echoes of the modern understanding of ESFM in some earlier writings on Western Australian forests that reach beyond timber yield alone. For example, the wastage of early, virtually unrestricted cutting was often bewailed with phrases such as '... a crime against coming generations...' (Royal Commission 1903, quoted in Lane Poole 1917, p. 1) and ' ... destroying an asset which is clearly the property of the nation, that is to say, the property of all future generations ...' (Lane Poole 1917, p. 1). Additionally, the Royal Commission of 1952 recommended steps to improve the health of the jarrah forest (Rodger 1952). These comments foreshadow current concepts of intergenerational equity and ecosystem health. Furthermore, the foresight of the Australian Association for the Advancement of Science in establishing the short-lived South Dandalup reserve has clear sympathy with contemporary concerns for biodiversity conservation. That these efforts to achieve sustainability found little support in the political arena suggests that sustainability at any level in Western Australian forests is unlikely without marked changes in social values and political viewpoint.

\section{Why have we not achieved sustainability despite $\mathbf{8 0}$ years of scientific-based forest management?}

The history of 'sustainable' exploitation of natural resources is discouraging at both local and global scales (Ludwig et al. 1993). Furthermore, Hilborn et al. (1995) demonstrated that biological overexploitation is almost universal at some point in the development of a potentially renewable resource and, even when biological overexploitation is avoided, economic overexploitation is the norm. They also demonstrate that to avoid overexploitation, there must be a deliberate willingness to forego attempts at maximising yield. Society has the knowledge to design management systems that will provide long-term sustained harvest even when tracking unpredictable environmental changes (Berkes et al. 2003). However, exploitation has not been controlled well enough to make the changes necessary to track changing biological productivity and biological understanding.
Hilborn et al. (1995) argued that successful management in the future will rest not so much on better science as on the implementation of better institutional arrangements for controlling exploitation and creating incentives for wiser behaviour.

We believe that Western Australia developed the necessary scientific expertise for effective forest management, but lacked the social awareness and institutional arrangements to apply it properly. Examples of such limitations abound:

The radical step of closing down a sufficient number of mills to reduce the annual turn-out to the increment of the forest is the obvious one, and would effect the whole of the object in view; but the democracy of Western Australia is not likely to take such a course, not even to the extent of closing down its own State sawmills, for the very easily understood reason that trees have at present no votes. Lane Poole (1920a, p. 33)

All sawmillers, practically without exception, appear to believe that they deserve "special consideration" when approaching the exhaustion of the permissible cut on their permit areas. Rodger (1952, p. 23)

This level of overcutting is necessary to support the established industry. Hansard (1974a)

The justification for over-harvest is dependent upon the social and commercial benefits that can occur as a consequence. Meagher et al. (1993, p. 27)

Overcutting was sometimes represented as a short-term aberration, to be corrected a decade into the future (e.g., Kessell 1935, Meagher et al. 1993), or priority was given to timber industry needs until the data necessary for sustained yield management became available (Forests Department 1956). Similar attitudes of development as the highest priority are reported for agricultural clearing in Western Australia as well (Beresford et al. 2001). Figure 6 is a pertinent example, where two early politicians are proud to be photographed felling a large jarrah tree. We can think of few contemporary politicians who would be photographed in such a situation today, reflecting a shift in social and political attitudes. It appears that sustainability has been low on the list of social and political priorities for immediate forest management and, as a consequence, it was seldom achieved.

\section{What are the consequences for fauna of sustained overcutting?}

The impacts of over a century of logging in the jarrah forest include marked alterations in age structure, species composition and canopy cover. The changes wrought by the unrestricted logging of the nineteenth and early twentieth centuries were noted by Wallace (1965, p.35): 'In the period prior to 1920 nearly one million acres of the jarrah forest were cut over for the removal of 750 million cubic feet of logs, causing a reduction of almost $50 \%$ in the forest canopy.' The focus of later management on timber production involved a selective removal of large, old trees and the logging of regrowth at maturity, further altering the age composition of stands. For example: 


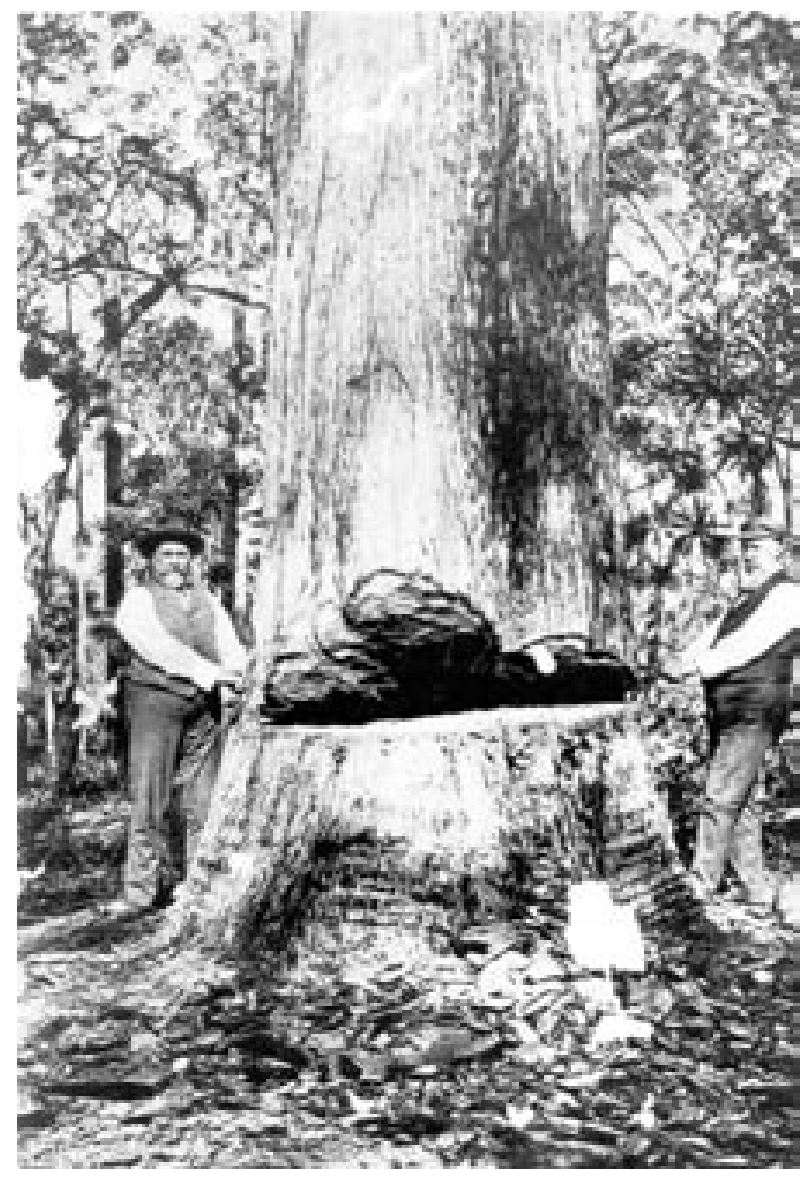

Figure 6. Sir John Forrest, once Premier of Western Australia (left) and Sir William Lyne (a Commonwealth politician) felling a jarrah tree c. 1907. (courtesy of the Battye Library, Western Australia).

When what remains of the present over-mature crop of jarrah and karri has been cut down, it is unlikely that specimens equal in bulk to what the forests have already yielded or still possess will be seen by future generations. When the State's forests have become "cultivated", trees will be cut when they reach maturity. Sentiment may dictate the preservation of a few for a period far beyond that of maturity, as reminders of the giants of former days, but whole forests of giant trees will no longer be seen. Lane Poole (1920, p. 130)

More recently, Abbott and Loneragan (1986, p.78) corroborated these actions:

Originally the jarrah [Eucalyptus marginata] forest produced trees of $150 \mathrm{~cm}$ d.o.b. [diameter over bark, measured 1.3 metres above ground level] over an estimated physiological rotation of 800 to 1000 years. Under management, the forests have been changed with the object of providing trees of d.o.b. c. $70 \mathrm{~cm}$ within 90 to 120 years. ... The great boles of long length which gave the virgin forest such a large volume of wood are unlikely to be grown again, other than in areas of the northern jarrah forest set aside from future timber production.

Further practices including the ringbarking of "larger trees of useless species or overmature and containing no merchantable timber' (Kessell 1928, p. 16) would have altered both age structure and the relative abundance of tree species. Although the estimated physiological rotation of jarrah is now accepted to be closer to 300 than to 800 years and the value of large, old trees is recognized explicitly in forest management (Stoneman et al. 1997), the cumulative impacts of decades of logging on the age structure and species composition of the jarrah forest cannot be overturned quickly.

Structural change is also documented in a shift of the biomass of the forest trees towards smaller age classes. Thus the 1952 Royal Commission observed:

It will be noted that despite the quantities which have been removed in trade operations, and losses due to fire, the estimates of the total quantity of timber standing in the forests have progressively increased. A certain number of trees in classes below 90in. G.B.H. have passed into the highest class since 1928, but the increase in the later estimates is mainly due to a gradual lowering of log standards with the increasing scarcity of log timber. As a result, many trees previously considered of doubtful merchantability can at present be considered merchantable. Rodger (1952, p.8)

More recently, Cribb (1985, p.22) claimed: 'By 2020 AD timber from mature jarrah and karri will be unobtainable for most uses. ... Unless alternatives to mature jarrah and karri are found, mills will close, jobs will be lost, and millions of dollars in Government revenue will disappear as the import bill for timber soars.' His solution was to use the large quantities of wood ' $\ldots$ in overcrowded stands of young jarrah, marri and karri that have regrown on the areas of forest originally felled around the turn of the century' (Cribb 1985, p. 23). Overall, the changes described suggest that fauna dependent on large, old trees or a continuous canopy are most likely to have suffered as a result of past forest management, consistent with the observation that differences in forest structure are an excellent indicator of changes in biodiversity within forest types (e.g., Kanowski et al. 2003).

Assessments of these changes in age structure and species composition on biodiversity conservation are controversial, in part because of the lack of early baseline studies (RAC 1993, McKenzie et al. 1996) and in part because few impact studies were published before the late 1990s (Calver and Dell 1998a). Abbott and Christensen (1994, 1996) claimed that impacts were negligible and not cumulative, while Nichols and Muir (1989) admitted that data were lacking but doubted that there were serious impacts. By contrast, Calver et al. $(1996,1998)$ and Calver and Dell (1998a, b) thought the question open for lack of evidence, while Mawson and Long (1994) believed that deleterious impacts were already occurring. Recent population studies (Rhind 1996, 1998) and impact experiments (Craig 1999; Morris et al. 2000) confirmed mortality of some vertebrates during logging operations or changes in distribution and abundance in the short and medium term. The Western Ringtail Possum Pseudocheirus occidentalis may be the species most seriously impacted (Burrows et al. 2001), while ground-dwelling mammals, some birds and terrestrial invertebrates appear either robust in the face of logging disturbances or adequately protected under current prescriptions (Craig 1999, Morris et al. 2000, Strehlow et al. 2002, Wardell-Johnson et al. 2004). 
Fauna using tree hollows have been of particular concern, with several authors speculating that the selective removal of large, old trees would alter the abundance and distribution of hollows (e.g., Saunders et al. 1985, Inions et al. 1989, Mawson and Long 1994 and Saunders and Ingram 1995). A recent risk assessment of hollow-using fauna in the south-west identified no species currently at high or immediate risk of decline, but called for further modelling of stand structure and detailed ecological studies of selected hollow-using species to substantiate the predictions (Abbott and Whitford 2002). Furthermore, McKenzie et al. (1996) noted that some faunal groups of the forested southwest of Western Australia have declined less markedly than those of other areas of the state, but cautioned that intensification of land-use was a concern.

The inappropriateness of seeking to attribute changes to single causes is illustrated most clearly by the complex of interacting factors involved in the multifarious impacts of the plant pathogen Phytophthora cinnamomi, regarded by Wardell-Johnson and Nichols (1991) as second only to agricultural clearing as a conservation problem in the south-west. Davison and Shearer (1989) suggested that, following Phytophthora infection in the forests of southwestern Australia, the forest may become more open, with increased exposure of fauna to exotic predators and colonization of the forest by predators from adjacent more open woodlands. Additionally, habitat and food plants may decline as susceptible plants in the understorey die and it has been speculated that some fire regimes may destroy soil microflora antagonistic to P. cinnamomi (Shearer and Tippett 1989). In addition, Banksia grandis is a significant reservoir for the pathogen in jarrah forest (Shea et al. 1978, Dell and Malajczuk 1989) and the incidence of B. grandis is positively related to opening the forest by logging and repeated low intensity fires (Shearer and Tippett 1989). Thus changes in fire regimes may be interactive with $P$. cinnamomi impacts. The impacts of logging must also be seen in the context of the extensive clearing for agriculture and fragmentation of remaining native vegetation occurring within and surrounding the State managed lands. Many of the complex interactions can only be assessed with the benefit of hindsight.

On balance, logging and its associated activities, past and present, appears neither the sole nor the most significant factor in fauna conservation in the jarrah forests. Several commentators have concluded that agricultural clearing, introduced predators and plant pathogens such as $P$. cinnamomi are more significant causes (e.g., WardellJohnson and Nichols 1991, McKenzie et al. 1996, Calver and Dell 1998b). However, timber production has left a legacy of a younger, more open forest with different habitat values for fauna and interacted with other threatening processes such as changed fire regimes and plant disease. The on-going consequences of that legacy deserve thorough assessment, including interactions with other established threats to conservation.

\section{How do we ensure more accountable progress towards sustainability?}

\section{Managerial reforms}

Internationally, there is growing recognition of the diverse values of forests, including timber production. Moreover, there is evidence that production forests can aid biodiversity conservation if timber-cutting practices closely resemble natural forest dynamics (e.g., Ehrlich 1996; Lindenmayer and Franklin 2000; Seydack 2000). Thus, there is a need for a shift from a policy of focussing on timber production by transforming forest structure and function to more naturalistic systems, which attempt to imitate natural forest dynamics. For example, Seydack (2000) has provided a model for the harvest of only the wood increment since the last cut in subtropical forests. In Western Australia, a more ecological focus may provide only modest yields in comparison with that to which society is accustomed. However, it would account for the highly heterogeneous vegetation types in the subdued landscapes of the jarrah forests (Wardell-Johnson and Horwitz 1996, 2000), allow avoidance of sensitive landscape features or units, and limit major structural change. Communities immediate to the forests could decide if this approach would provide them with greater certainty than those presently applying.

Rivlin (1993, p. 256) argued that appropriate managerial reform is likely to require two essential steps:

The evolution toward sustainable forestry requires, at a minimum, recognition of the limitations of current knowledge and of the risk that human intervention will do irreversible harm before enough knowledge accumulates to identify the priorities of sustainable forestry. This recognition leads to a double strategy: (1) intensify research on how forest ecosystems work and (2) preserve options for the future.

We concur and believe that Rivlin's two strategies are exemplified in adaptive management and the precautionary principle. Both emphasize that uncertainty dominates much environmental management, particularly concerning the sustainable management of potentially renewable resources. Adaptive management reduces that uncertainty by gathering sound information through management practice, while the precautionary principle dictates that in areas of uncertainty the benefit of the doubt should be given to environmental protection. We discuss the potential application of each approach to Western Australian forest management, followed by an assessment of their role in recent political initiatives to draft a new forest management plan.

Adaptive management treats different management actions in space and time as experimental treatments to increase understanding of the system being managed (Walters and Holling 1990; Boyce 1997; Lee 1999). Numerous authors concur that such a hypothesis-testing framework, incorporating quantifiable standards that can be falsified, is essential for comparing the long-term effectiveness of different management practices (e.g., Murphy and Noon 1991; Everett et al 1994; Norton and 
May 1994). The alternative of 'superstitious learning' (erroneous connections between cause and effect) is enhanced when the focus is on the process and not on the outcomes (Levitt and March 1988, p. 326). While the focus is on process, it is possible to have an Environmental Management System (e.g., ISO 14001 guidelines) that faithfully captures unsustainable environmental management (Geno 2001). For example, counting tree hollows may give the misleading impression that hollow-using fauna are secure, whereas monitoring of population trends in indicator taxa could reveal serious declines (McCarthy et al. 1994, Wardell-Johnson et al. 2004, see also the recommendations for monitoring in Abbott and Whitford 2002).

Boyce (1997, pp. 231-232) documented numerous examples of successful problem-solving using adaptive management and Noss (1993) claimed that chances of success were greatest when broadly-based scientific panels advised managers. We also endorse using integrated, mediation-based approaches and commissioning empirical studies, where called for, as part of these procedures (e.g., Yaffee 1994; Cocks et al. 1996). However, the effective use of adaptive management implies an information-rich environment whereby yield forecasts allow a publicly scrutinised process of allocation of timber volumes from publicly managed land and actual adherence to standards of logging practices are appraised (Lindenmayer and Recher 1998).

Suggested alternative silvicultural approaches can be seen as a basis for dialogue within such a framework to develop adaptive management approaches for the south-west forests that are testable within an adaptive management framework. Important issues for consideration include logging rotations, habitat retention within logging areas, boundaries of reserves and corridors, the desirable tree species mix in regrowth areas and the forest structure to be attained before further cutting.

The precautionary principle is the second major component. It is defined as:

'Where there are threats of serious or irreversible damage, lack of full scientific certainty should not be used as a reason for postponing measures to prevent environmental degradation. In the application of the precautionary principle, public and private decisions should be guided by: careful evaluation to avoid, wherever practicable, serious or irreversible damage to the environment; and, (ii) an assessment of the risk-weighted consequences of various options' The Intergovernmental Agreement on the Environment, May 1992, quoted in Deville and Harding (1997, p. 13)

One of its great strengths is an explicit focus on scientific uncertainty, placing the burden of proof on industry rather than on environmental advocates and prioritizing preventive management to avert possible, but not certain, damage (Garcia 1994). Precaution should increase if either the threat or the uncertainty is great (Deville and Harding 1997). Given the concentration of rare and endangered biota in Western Australian hardwood forests (e.g., Young 1994; Main 1996; Maxwell et al. 1996), warnings against complacency (McKenzie et al. 1996) and calls for on-going monitoring (Abbott and Whitford 2002), we believe that a high level of precaution is indicated.

Recent attempts to quantify applications of the precautionary principle using statistical power analysis (Buhl-Mortensen and Welin 1998, risk analysis Rogers et al. 1997) or Bayesian statistics (Varis and Kuikka 1997) provide rigorous standards for monitoring to ensure that critical indicators remain within acceptable boundaries. The focus on assessing the response of indicators to management activities allows ready integration of the precautionary principle with adaptive management. Thus, activities may be allowed to proceed in an experimental framework providing their impacts lie within specified limits and remedial actions are prescribed if they are exceeded (Deville and Harding 1997). The setting of those limits and the remedial actions required should involve all stakeholders (Calver et al. 1999).

\section{Political and institutional reforms}

The social, political and institutional pressures that have resulted in overcutting in the jarrah forests share much in common with other examples of resource use, including: short-term planning, with a greater emphasis on immediate gains rather than long-term ones (Rivlin 1993, Lackey 1996); (ii) resisting change, with those standing to lose by change often having greater political power than those seeking it, and the change often portrayed in a 'winners and losers' context (Rivlin 1993, Maser 1994, Lackey 1996); (iii) complex decisions, characterized by diverse options and values-based rather than sciencebased judgements (Rivlin 1993, Lackey 1996); and (iv) financial valuing, in which the benefits expressed readily in monetary terms receive priority in decisionmaking (Rivlin 1993). In the face of these complexities, Rivlin (1993) and Lackey (1996) argue for better public information about available options and their likely consequences to aid in a decision-making process that is ultimately social process, not scientific.

Western Australia now has an opportunity to move in this direction. Following a change of State Government in 2001, the newly constituted Conservation Commission of Western Australia released a discussion paper on proposals for a new Forest Management Plan for Western Australia (Conservation Commission 2002a) and an extensive draft plan (Conservation Commission 2002c), which has now developed into a full proposal (http://www.conservation.wa.gov.au/news.htm?artID = $8 \&$ NewsName $=$ Proposed + Forest + Management $+\mathrm{Pl}$ an). This sets clear objectives, including the adaptive management protocols for assessing their success and the precautionary measures accompanying their implementation. We are cautiously optimistic that these steps may move Western Australia closer to sustainable forest management. In particular, the proposed plan is characterized by full disclosure of yield information and an independent assessment of procedures. 


\section{Conclusion}

Our overview indicates that the history of jarrah forest logging in Western Australia is one of sustained unsustainability, in which pressures for a high, immediate level of timber production clashed with concerns over long-term sustained yield. Even during recent decades when multiple-use management philosophies underpinned prescriptions, broad-scale rather that finescale management was used in a way that appears to have been detrimental to biodiversity conservation and counter to the best practice of adaptive management (Wardell-Johnson and Horwitz 1996, 2000). Maintaining the level of the cut above sustainable limits restricted the flexibility to vary prescriptions according to vegetation complex or community type, avoid sensitive areas and limit biophysical damage and possible compromises to ecosystem health. Systemic overcutting also restricted a shift from transformative to naturalistic management regimes at a local scale and, in the long-term, probably led to a decline in general public support for logging in State managed lands. This decline in support is likely to persist without a demonstrable commitment to reverse species and ecosystem declines, prevent intensification of introduced taxa, and increase efforts towards the rehabilitation of degraded areas.

However, there is real opportunity for change. Approximately 80 years ago, an optimistic Conservator of Forests wrote:

Some foresters who have visited this State have been so disheartened by the condition of affairs they have found that they have said that there will be no forestry in Western Australia until the last tree has been cut down. I do not hold this pessimistic view, but consider that, by a publicity campaign, the democracy will realise the wealth that the forests represent. It is true that trees to-day have no votes, but when the people develop a forest conscienceness (sic) the position will be entirely altered, and they themselves will see to it that the forest policy is maintained and the forests are used for the benefit of the community as a whole for ever, and not for the benefit of the few sawmillers, timber hewers, and timber merchants of to-day. Lane Poole (1920, p. 34)

Recent developments in Western Australia indicate that the State is entering a fourth era in the management of its forests, which may yet see this vision fulfilled. At a scientific level, the move to sustainability is characterised by a growing recognition of the environmental heterogeneity of the south-west forests, the need to manage at a finer scale than ever before and the acceptance that ecologically sustainable logging is possible, but not yet achieved. The proposed forest management plan shows a striking social and political change by making the explicit commitment to sustainability shown to be so necessary by historical experience if ESFM is to be attained. This shift in the political climate is the most significant hopeful sign for the forming of a political will to implement ESFM in the jarrah forests. Political will and scientific recognition of the need to manage to sustain environmental heterogeneity may together protect the diversity of habitats in the jarrah forests necessary for the long-term conservation of their fauna.

\section{Acknowledgements}

We thank Vi Saffer for substantial assistance in literature searches and Angela Wardell-Johnson for sociological insight. We also thank, without implication, Ron
Wooller and three anonymous reviewers for constructive comments on an earlier draft of the manuscript and Dan Lunney for perceptive editorial guidance.

\section{References}

Abbott, I. and Christensen, P., 1994. Application of ecological and evolutionary principles to forest management in Western Australia. Australian Forestry 57: 109-122.

Abbott, I. and Christensen, P., 1996. Objective knowledge, ideology and the forests of Western Australia. Australian Forestry 59: 206-212.

Abbott, I. and Loneragan, O., 1986. Ecology of jarrah (Eucalyptus marginata) in the northern jarrah forest of Western Australia. Department of Conservation and Land Management, Perth, Western Australia.

Abbott, I. and Whitford, K. R., 2002. Conservation of vertebrate fauna using hollows in forests of south-west Western Australia: strategic risk assessment in relation to ecology, policy, planning, and operations management. Pacific Conservation Biology 7: 240-255.

Abbott, I., Wills, A., Burbidge, T. and van Huerck, P., 2001. Arthropod faunas of crowns of jarrah (Eucalyptus marginata) and marri (Corymbia calophylla) in a Mediterranean-climate forest: A preliminary regional-scale comparison. Australian Forestry 63: 21-26.

Attiwill, P. M., 1994. Ecological disturbance and the management of eucalypt forests in Australia. Forest Ecology and Management 73: 301-346.
Beggs, B. J., 1982. General working plan for State Forests in Western Australia. Working Plan No. 87 Part I. Forests Department of Western Australia, Perth, Western Australia.

Beresford, Q., Bekle, H., Philips, H. and Mulcock, J., 2001. The salinity crisis: landscape, communities and politics. University of Western Australia Press, Perth, Western Australia.

Borschmann, G., 1999. The people's forest: a living history of the Australian bush. The People's Forest Press, Blackheath, NSW.

Boyce, S. G., 1995. Landscape forestry. John Wiley and Sons, New York.

Boyce, M. S., 1997. Population viability analysis: adaptive management for threatened and endangered species. Pp. 226238 in Ecosystem management: applications for sustainable forest and wildlife resources, edited by M. S. Boyce and A. Haney, Yale University Press,

Bradshaw, F. J., 1991. Treemarking and silvicultural treatment in the jarrah forest. Department of Conservation and Land Management, Perth, Western Australia.

Bradshaw, F. J. and Lush, A. R., 1981. Conservation of the karri forest. Forests Department of Western Australia, Perth. 
Bradshaw, F. J., Adams, R., Sneeuwjagt, R., Low, K., Havel, J. J., Bartle, J. R. and Stoneman, G. L., 1991. The jarrah forest: A case study in multiple use. Pp. 1-21 in Forest management in Australia, edited by F. H. McKinnell, E. R. Hopkins and J. E. D. Fox, Surrey Beatty and Sons, Chipping Norton, NSW.

Braithwaite, L. W., 1996. Conservation of arboreal herbivores: The Australian scene. Australian Journal of Ecology 21: 21-30.

Breidahl, R. and Hewett, P. J., 1995. A review of silvicultural research in the karri (Eucalyptus diversicolor) forest. CALMScience 2: $51-100$.

Buchy, M. and Hoverman, S., 1999. Understanding public participation in forest planning in Australia: How can we learn from each other? Australian National University Forestry Occasional Paper 99.2, Canberra, Australia.

Buhl-Mortensen, L. and Welin, S., 1998. The ethics of doing policy relevant science: the precautionary principle and the significance of non-significant results. Science and Engineering Ethics 4: 401-412.

Bunn, S. E. and Davies, P. M., 1990. Why is the stream fauna of south-western Australia so impoverished? Hydrobiologia 194: 169-176.

Burrows, N. D., Ward, B. and Robinson, A. D., 1995. Jarrah forest fire history from stem analysis and anthropological evidence Australian Forestry 58: 7-16.

Burrows, N., Christensen, P., Hopper, S., Ruprecht, J. and Young, J., 2001. Ministerial condition 11: Panel report Part 1. Department of Conservation and Land Management, unpublished report.

Burrows, N. and Wardell-Johnson, G., 2003. Fire and plant interactions in forested ecosystems of south-west Western Australia. Pp. 225-268 in Fire in ecosystems of south-west Western Australia: Impacts and management, edited by I. Abbott and N. Burrows, Backhuys Publishers, Leiden, The Netherlands.

CALM, 1989. Manual of hardwood logging specifications for management for hardwood logging specifications operations in the southwest of Western Australia. Department of Conservation and Land Management, Perth, Western Australia.

CALM, 1992. Management strategies for the south-west forests of Western Australia - a review. Draft for public comment. Department of Conservation and Land Management, Perth, Western Australia.

CALM, 1994. Land and Forests Commission. Forest Management Plan 1994-2003. Department of Conservation and Land Management, Perth, Western Australia.

Calow, P., 1998a. Sustainable development. Pp. 733-734 in The encyclopedia of ecology and environmental management, edited by P. Calow, Blackwell Science, Oxford.

Calow, P., 1998b. Sustainable yield. Pp. 734 in The encyclopedia of ecology and environmental management, edited by P. Calow, Blackwell Science, Oxford.

Calver, M. C. and Dell, J., 1998a. Conservation status of mammals and birds in south-western Australian forests. I. Is there evidence of direct links between forestry practices and species decline and extinction? Pacific Conservation Biology 4: 296-314.

Calver, M. C. and Dell, J., 1998b. Conservation status of mammals and birds in south-western Australian forests. II. Are there unstudied, indirect or long-term links between forestry practices and species decline and extinction? Pacific Conservation Biology 4: 315-325.
Calver, M. C., Bradley, J. S. and Wright, I. W., 1999. Towards scientific contributions in applying the precautionary principle: an example from Western Australia Pacific Conservation Biology 5: 63-72.

Calver, M. C., Dickman, C. R., Feller, M. C., Hobbs, R. J., Horwitz, P., Recher, H. F. and Wardell-Johnson, G., 1998. Towards resolving conflict between forestry and conservation in Western Australia Australian Forestry 61: 258-266.

Calver, M. C., Hobbs, R. J., Horwitz, P. and Main, A. R., 1996. Science, principles and forest management: a response to Abbott and Christensen Australian Forestry 59: 1-6.

Carron, L. T., 1985. A history of forestry in Australia. Australian National University Press, Canberra, Australia.

Chapman, A. and Dell, J., 1985. Biology and zoogeography of the amphibians and reptiles of the Western Australian wheatbelt. Records of the Western Australian Museum 12: 1-46.

Chindarsi, K. A., 1997. The logging of Australian native forests. The Australian Quarterly 69: 86-104.

Cocks, R. D., Ive, J. R. and Clark, J. I., 1996. Forest issues: processes and tools for inventory, evaluation, mediation and allocation. CSIRO Australia, Canberra.

Conacher, A., 1983. Environmental management implications of intensive forestry practices in an indigenous forest ecosystem: a case study from south-western Australia. Pp. 117-151 in Progress in resource management and environmental planning, edited by $\mathrm{T}$. O'Riordan and K. V. Turner, John Wiley \& Sons, New York.

Conservation Commission of Western Australia, 2002a. A new forest management plan for Western Australia. Discussion paper January 2002. Conservation Commission of Western Australia, Perth, Western Australia.

Conservation Commission of Western Australia, 2002c. Draft forest management plan July 2002. Conservation Commission of Western Australia, Perth, Western Australia.

Craig, M. D., 1999. The short-tem impacts of timber harvesting on the jarrah forest avifauna. Unpublished $\mathrm{Ph} \mathrm{D}$ thesis, University of Western Australia, Perth, Western Australia.

Cribb, A., 1985. New timber from a new forest. Landscope 1: 22-25.

Davey, S. M., Hoare, J. R. L., Binning, C. and Bright, C., 1997. Assessment of ecologically sustainable forest management for Regional Forest Agreements. Pp. 235-246 in Preparing for the 21st century, edited by E. Bachelard and A. G. Brown, Institute of Foresters of Australia, Canberra, Australia.

Davey, S. M., Hoare, J. R. L. and Rumba, K. E., 2002. Science and its role in Australian Regional Forest Agreements. International Forestry Review 4: 39-55.

Dargavel, J., 1995. Fashioning Australia's forests. Oxford University Press, Melbourne.

Dargavel, J., 1998. Politics, policy and process in the forests. Australian Journal of Environmental Management 5: 25-30.

Davey, S. M. and Norton, T. W., 1990. State forests in Australia and their role in wildlife conservation. Proceedings of the Ecological Society of Australia 16: 323-345.

Davison, E. M. and Shearer, B. L., 1989. Phytophthora species in indigenous forests in Australia. New Zealand Journal of Forestry Science 19: 277-289.

Davey, S. M. and Norton, T. W., 1990. State forests in Australia and their role in wildlife conservation. Proceedings of the Ecological Society of Australia 16: 323-345. 
Dell, B., Havel, J. J. and Malajczuk, N., editors,1989. The jarrah forest: a complex Mediterranean ecosystem. Dordrecht, Kluwer Academic Publishers.

Deville, A. and Harding, R., 1997. Applying the precautionary principle. The Federation Press, Sydney.

Deville, A. and Turpin, T., 1996. Indicators of research relevance to ecologically sustainable development and their integration with other R- and - D indicators in the Asia-Pacific region. Chemosphere 33: 1777-1800.

Ehrlich, P. R., 1996. Conservation in temperate forests: what do we need to know and do? Forest Ecology and Management 85: 9-19.

Elkins, P., Simon, S., Deutsch, L., Folke, C. and de Groot, R., 2003. A framework for the practical application of the concepts of critical natural capital and strong sustainability. Ecological Economics 44: 165-185.

Everett, R., Oliver, C., Saveland, J., Hessburg, P., Diaz, N. and Irwin, L., 1994. Adaptive ecosystem management. Pp. in Volume II: Ecosystem management: principles and applications, edited by M. E. Jensen and P. S. Bourgeron, USDA Forestry Service General Technical Report PNW-GTR-318.

Eyre, T. J. and Smith, A. P., 1997. Floristic and structural habitat preferences of yellow-bellied gliders (Petaurus australis) and selective logging impacts in southeast Queensland, Australia. Forest Ecology and Management 98: 281-295.

Ferguson, I. S., 1996. Sustainable forest management. Oxford University Press, Oxford.

Ferguson, I. F., Adams, M., Bradshaw, J., Davies, S., McCormack, R. and Young, J., 2001a. Calculating sustained yield for the Forest Management Plan (2004-2013): A preliminary review. Report to the Conservation Commission of WA by the Independent Panel. Conservation Commission of Western Australia, Perth

Ferguson, I. F., Adams, M., Bradshaw, J., Davies, S., McCormack, R. and Young, J., 2001b. Stage 2 Progress Report. Calculating sustained yield for the Forest Management Plan (2004-2013): A preliminary review. Report to the Conservation Commission of WA by the Independent Panel. Conservation Commission of Western Australia, Perth.

Ferguson, I. F., Adams, M., Brown, M., Cork, S., Egloff, B. and Wilkinson, G., 1997. Assessment of ecologically sustainable forest management in the south-west forest region of Western Australia. Report of the Independent Expert Advisory Group, Commonwealth and Western Australian Regional Forest Agreement Steering Committe, Perth.

Florence, R. G., 1996. Ecology and silviculture of eucalypt forests. CSIRO Publishing, Collingwood, Victoria.

Forests Department of Western Australia, 1956. Working plan no. 79. General working plan 1956, Western Australia. Working plan area jarrah, karri, wandoo. Forests Department of Western Australia, Perth, Western Australia.

Forests Department of Western Australia, 1971. Forestry in Western Australia. Forests Department of Western Australia, Perth, Western Australia.

Forests Department of Western Australia, 1977. Working plan no. 86. of 1977. Part I. Forests Department of Western Australia, Perth, Western Australia.

Forests Department of Western Australia, 1987. Working plan no. 79. General working plan 1956, Western Australia. Working plan area jarrah, karri, wandoo. Forests Department of Western Australia, Perth, Western Australia.
Garcia, S., 1994. The precautionary principle: its implications in capture fisheries management. Ocean and Coastal Management 22: 99-125.

Garnett, S. T. and Crowley, G. M., 2000. The action plan for Australian birds. Environment Australia/Birds Australia, Canberra.

Geno, B. J., 2001. Competing forestry management paradigms in Australian state forests. Pp. 198-211 in Environment, society and natural resource management: theoretical perspectives from Australasia and the Americas, edited by G. Lawrence, V. Higgins and S. Lockie, Edward Elgar, Cheltenham.

Gill, A.M., Moore, P.H.R., McCarthy, M.A. and Lang, S., 1997. Contemporary fire regimes in the forests of southwestern Australia. Commonwealth of Australia/State of Western Australia.

Gioia, P. and Pigott, J. P., 2000. Biodiversity assessment: a case study in predicting richness from the potential distributions of plant species in the forests of south-western Australia. Journal of Biogeography 27: 1065-1078.

Good, R., 1995. Ecologically sustainable development in the Australian Alps. Mountain Research and Development 15: 251258.

Goodland, R., 1995. The concept of environmental sustainability. Annual Review of Ecology and Systematics 26: 1-24.

Hansard, 1974a. WA Parliament, Legislative Assembly questions on notice, No. 19, 17/10/1974

Hansard, 1974b. WA Parliament, Legislative Assembly questions on notice, Nos. 18-19, 27/11/1974.

Hansard, 1974c. WA Parliament, Legislative Assembly questions on notice, No. 67, 28/11/1974.

Harris, A. C., 1954. Report on the operations of the Forests Department for the year ended 30th June, 1954. Forests Department of Western Australia, Perth, Western Australia.

Harris, A. C., 1955. Report on the operations of the Forests Department for the year ended 30th June, 1955. Forests Department of Western Australia, Perth, Western Australia.

Harris, J. M. and Goodwin, N. R., 2001. Volume introduction. $\mathrm{Pp}$. in A survey of sustainable development: social and economic dimensions, edited by J. M. Harris, T. A. Wise, K. P. Gallagher and N. R. Goodwin, Island Press, Washington.

Harris, A. C. and Wallace, W. R., 1959. Controlled burning in Western Australian forest practice. Forests Department of Western Australia, Perth, Western Australia.

Havel, J. J., 1989a. Land use conflicts and the emergence of multiple use. Pp. 281- in The jarrah forest: a complex Mediterranean ecosystem, edited by B. Dell, J. J. Havel and N. Malajczuk, Kluwer Academic Publishers, Dordrecht.

Havel, J. J., 1989b. Conservation in the northern jarrah forest. Pp. 379-398 in The jarrah forest: a complex Mediterranean ecosystem., edited by B. Dell, J. J. Havel and N. Malajczuk, Kluwer Academic Publishers, Dordrecht.

Helms, J. A., Ed., 1998. The dictionary of forestry. Bethseda, MD, Society of American Foresters and CABI Publishers.

Hilborn, R., Walters, C. J. and Ludwig, D., 1995. Sustainable exploitation of renewable resources. Annual Review of Ecology and Systematics 26: 45-68.

Horwitz, P., 1997. Comparative endemism and richness of the aquatic invertebrate fauna in peatlands and shrublands of far south-western Australia. Memoirs of the Museum of Victoria 56: $313-321$ 
Horwitz, P. and Calver, M. C., 1998. Credible science? Evaluating the Regional Forest Agreement process in Western Australia. Australian Journal of Environmental Management 5: 213-225.

Inions, G. B., Tanton, M. T. and Davey, S. M., 1989. Effects of fire on the availability of hollows in trees used by the Common Brushtail Possum, Trichosurus vulpecula Kerr, 1792, and the Ringtail Possum, Pseudocheirus peregrinus Boddaerts, 1785. Australian Wildlife Research 16: 449-458.

Johnson, N., 1993. Introduction. Pp. 11-16 in Defining sustainable forestry, edited by G. H. Aplet, N. Johnson, J. T. Olson and V. A. Sample, Island Press, Washington DC.

Kanowski, J., Catterall, C. P., Wardell-Johnson, G.W., Proctor, H., Reis, T. and Tucker, N.I.J., 2003. Development of forest structure on cleared rainforest land in north-eastern Australia under different styles of reforestation. Forest Ecology $\mathbb{E}$ Management 183: 265-280.

Kessell, S. L., 1922. Report of the Forests Department for the year ended 30th June, 1922. Forests Department of Western Australia, Perth, Western Australia.

Kessell, S. L., 1928. Forestry and forest resources, Western Australia. A statement prepared for the British Empire Forestry Conference (Australia and New Zealand) 1928. Government Printer, Perth, Perth, Western Australia.

Kessell, S. L., 1932. Report on the operations of the Forests Department for the year ended 30th June, 1932. Forests Department of Western Australia, Perth, Western Australia.

Kessell, S. L., 1935. Forestry and forest resources, Western Australia. Progress statement prepared for the British Empire Forestry Conference (South Africa) 1935. Government Printer, Perth, Perth, Western Australia.

Kessell, S. L., 1938. Report on the operations of the Forests Department for the year ended 30th June, 1938. Forests Department of Western Australia, Perth, Western Australia.

Lackey, R. T., 1996. Pacific salmon, ecological health and public policy. Ecosystem Health 2: 61-68.

Lane Poole, C. E., 1917. Annual report of the Woods and Forests Department for the year ended 31st December, 1916. Woods and Forests Department, Western Australia, Perth, Western Australia.

Lane Poole, C. E., 1918. Annual report of the Woods and Forests Department for the year ended 31st December, 1917. Woods and Forests Department, Western Australia, Perth, Western Australia.

Lane Poole, C. E., 1920a. Statement prepared for the British Empire Forestry Conference, London, 1920. Government Printer, Perth, Perth, Western Australia.

Lane Poole, C. E., 1920b. Notes on the forests and forest products and industries of Western Australia. Forests Department of Western Australia, Perth, Western Australia.

Lane-Poole, C.E., 1920c. Report on the operations of the Forests Department for the year ended 30th June, 1920. Forests Department of Western Australia, Perth, Western Australia.

Lane Poole, C. E., 1921. A primer of forestry: with illustrations of the principal forest trees of Western Australia. Department of Education, Western Australia, Perth, Western Australia.

Lee, K. N., 1999. Appraising adaptive management. Conservation Ecology 3(2): 3. [online] URL: http://www.consecol.org/vol3/ iss2/art3 Levin 1993

Levitt, B., and March, J. G., 1988. Organizational learning. Annual Review of Sociology 14: 319-340.
Lindenmayer, D. B. and Franklin, J. F., 2000. Managing unreserved land for biodiversity conservation: the importance of the matrix. Pp. 13-25 in Conservation in production environments: managing the matrix, edited by J. Craig, N. Mitchell and D. A. Saunders, Surrey Beatty and Sons, Chipping Norton, NSW.

Lindenmayer, D. B. and Franklin, J. F., 2002. Conserving forest biodiversity: a comprehensive multiscaled approach. Island Press, Washington, DC.

Lindenmayer, D., Margules, C. R. and Botkin, D. B., 2000. Indicators of ecologically sustainable forest management. Conservation Biology 14: 941-950.

Lindenmayer, D. B. and Recher, H. F., 1998. Aspects of ecologically sustainable forestry in temperate eucalypt forests beyond an expanded reserve system. Pacific Conservation Biology 4: 4-10.

Ludwig, D. Hilborn, R. and Walters, C.,1993. Uncertainty, resource exploitation and conservation: lessons from history. Science 260: 17-36.

Main, B. Y., 1996. Terrestrial invertebrates in south-west Australian forests: the role of relict species and habitats in reserve design. Joumal of the Royal Society of Western Australia 79: 277-280.

Majer, J. D., Recher, H. F., Heterick, B. E. and Postle, A. C., 2002. The canopy, bark, soil and litter invertebrate fauna of the Darling Plateau and adjacent woodland near Perth, Western Australia, with reference to the diversity of forest and woodland invertebrates. Pacific Conservation Biology 7: 229-239.

Maser, C., 1994. Sustainable forestry: philosophies, science and economics. St. Lucie Press, Florida.

Maser, C., 1999. Ecological diversity in sustainable development. Lewis Publishers, Boca Raton, Florida.

Mawson, P. R. and Long, J. L., 1994. Size and age parameters of nest trees used by four species of parrot and one species of cockatoo in South-west Australia. Emu 94: 149-155.

Maxwell, S., Burbidge, A. A. and Morris, K., 1996. The 1996 action plan for Australian marsupials and monotremes. Wildlife Australia, Canberra, Australian Capital Territory.

McCarthy, M. A., Pearce, J. L. and Burgman, M. A., 1994. Use and abuse of wildlife models for determining habitat requirements of forest fauna. Australian Forestry 57: 82-85.

McCaw, W. L. and Burrows, N. D., 1989. Fire management. Pp. 317-334 in The jarrah forest: a complex Mediterranean ecosystem., edited by B. Dell, J. J. Havel and N. Malajczuk, Kluwer Academic Publishers, Dordrecht.

McIlroy, J. C., 1978. The effects of forestry practices on wildlife in Australia: a review. Australian Forestry 39: 78-94.

McKenzie, N. L., Hopper, S. D., Wardell-Johnson, G. and Gibson, N., 1996. Assessing the conservation reserve system in the jarrah forest region. Journal of the Royal Society of Western Australia 79: 241-248.

Meagher, T., Campbell, F., Shepherd, K. and Kitchener, D., 1993. Report of the scientific and administrative committee inquiry into aspects of conditions set pursuant to the Environmental Protection Act 1986 for the proposed amendments to the 1987 forest management plans and timber strategy and proposals to meet environmental conditions on the regional plans and the WACAP ERMP proposal. Report to the Hon. Kevin J. Minson, MLA, Western Australian Minister for the Environment, Perth, Western Australia.

Mills, J., 1989. The impact of man on the northern jarrah forest from settlement in 1829 to the Forests Act 1918. Pp. 229-279 in The jarrah forest: a complex Mediterranean ecosystem., edited by B. Dell, J. J. Havel and N. Malajczuk, Kluwer Academic Publishers, Dordrecht. 
Mills, J., 1986. The timber people: a history of Bunnings Limited. Bunnings Limited, Perth, Western Australia.

Mills, J., 2002. Kim Kessell: a first class sensible bloke. Pp. 357-365 in Australia's ever-changing forests V, edited by J. Dargavel, D. Gaughwin and B. Libbis, Centre for Resource and Environmental Studies at the Australian National University and the Australian Forest History Society Inc., Canberra, ACT.

Morgan, D. L., Gill, H. S. and Potter, I. C., 1998. Distribution, identification and biology of freshwater fishes in south-western Australia. Records of the Western Australian Museum Supplement No. 56.

Morris, K., Johnson, B., Rooney, J. and Ward, C., 2000. The short-term impacts of timber harvesting and associated activities on the abundance of medium-sized mammals in the Jarrah forest of Western Australia. Pp. 60-70 in Conservation in production environments: managing the matrix, edited by J. L. Craig, N. Mitchell and D. A. Saunders, Surrey Beatty and Sons, Chipping Norton, NSW.

Murphy, D. D. and Noon, B. D., 1991. Coping with uncertainty in wildlife biology. Journal of Wildlife Management 55: 773-782.

Nichols, O. G. and Muir, B., 1989. Vertebrates of the jarrah forest. Pp. 133-153 in The jarrah forest: a complex Mediterranean ecosystem., edited by B. Dell, J. J. Havel and N. Malajczuk, Kluwer Academic Publishers, Dordrecht.

Norton, T. W., 1996. Conserving biological diversity in Australia's temperate eucalypt forests. Forest Ecology and Management21-33.

Norton, T. W. and Kirkpatrick, J. B., 1995. Sustainable forestry - the urgency to make the myth a reality. Pp. 240248 in Conserving biodiversity: threats and solutions, edited by R. Bradstock, T. Auld, D. Keith, R. Kingsford, D. Lunney and D. Sivertsen, Surrey Beatty and Sons, Chipping Norton, New South Wales.

Norton, T. W. and May, S. A., 1994. Towards sustainable forestry in Australian temperate eucalypt forests: Ecological impacts and priorities for conservation, research and management. Pp. 10-30 in Ecology and sustainability of southern temperate ecosystems, edited by T. W. Norton and S. R. Dovers, CSIRO Publications, Melbourne.

Noss, R. F., 1993. Sustainable forestry or sustainable forests? Pp. 17-43 in Defining sustainable forestry, edited by G. H. Aplet, N. Johnson, J. T. Olson and V. A. Sample, Island Press, Washington, D.C.

Nunn, G. W. M., 1957. Forest management in the eucalypt forests of the south-west of Western Australia. Statement prepared for the Seventh British Commonwealth Forestry Conference, 1957. Forests Department of Western Australia, Perth, Western Australia.

Peet, G. B. and McCormick, J., 1971. Short term responses from controlled burning and intense fires in the forests of Western Australia. Forestry Department of Western Australia Bulletin.

Pickering, G.W., 1922. Report of Royal Commission on forestry 1922. Government of Western Australia, Perth, Western Australia.

Podger, F. D., 1972. Phythophthora cinnamomi, a cause of lethal disease in indigenous plant communities in Western Australia. Phytopathology 62: 972-981.

RAC, 1991. Forest and timber inquiry draft report Volume 1. Commonwealth of Australia, Canberra.

RAC, 1992. Forest and timber inquiry final report Volume 1. Commonwealth of Australia, Canberra.
RAC, 1993. Ecological impacts of forest use: a survey of completed research. Research paper no. 9. Resource Assessment Commission, Canberra.

Recher, H. F., 1996. Conservation and management of eucalypt forest vertebrates. Pp. 339-388 in Conservation of faunal diversity in forested landscapes, edited by R. M. DeGraaf and R. I. Miller, Chapman and Hall, London.

Rhind, S. G., 1996. Habitat tree requirements and the effects of removal during logging on the marsupial brush-tailed phascogale (Phascogale tapoatafa tapoatafa) in Western Australia. The Western Australian Naturalist 21: 1-21.

Rhind, S. G., 1998. Ecology of the brush-tailed phascogale in jarrah forest of southwestern Australia. Unpublished Ph D thesis, Murdoch University, Perth, Western Australia.

Rhind, S. G., Bradley, J. S. and Cooper, N. K., 2001. Morphometric variation and taxonomic status of brush-tailed phascogales, Phascogale tapoatafa (Meyer, 1793) (Marsupialia: Dasyuridae). Australian Journal of Zoology 49: 345-368.

Rivlin, A.M., 1993. Values, institutions and sustainable forestry. Pp. 255-259 in Defining sustainable forestry, edited by G. H. Aplet, N. Johnson, J. T. Olson and V. A. Sample, Island Press, Washington, D.C.

Roberts, J. D., Wardell-Johnson, G. and Barendse, W., 1990. Extended descriptions of two new species of Geocrinia (Anura: Myobatrachidae) from south-western Australia, with comments on the status of G. lutea. Records of the Western Australian Museum 14: 427-437.

Roberts, J. D., Horwitz, P., Wardell-Johnson, G., Maxson, L. R. and Mahony, M. J., 1997. Taxonomy, relationships and conservation of a new genus and species of Myobatrachid frog from the high rainfall region of southwestern Australia. Copeia (2): 373-381.

Robertson, J., 1956. A history of the timber industry of Western Australia. Unpublished Honours thesis, the University of Western Australia, Perth, Western Australia.

Rodger, G.J., 1952. Report of the Royal Commission appointed to inquire into and report upon Forestry and Timber matters in Western Australia. Government of Western Australia, Perth, Western Australia.

Rogers, M. F., Sinden, J. A. and De Lacy, T., 1997. The precautionary principle for environmental management: a defensive-expenditure application. Journal of Environmental Management 51: 343-360.

Rundle, G. E., 1996. History of conservation reserves in the south-west of Western Australia. Journal of the Royal Society of Western Australia 79: 225-240.

Salwasser, H., 1997. Conservation biology and the management of natural resources. Pp. in Principles of conservation biology, edited by G. K. Meffe and C. R. Carroll, Sinauer Associates, Inc., Sunderland, Massachusetts.

Salwasser, H., MacCleery, D. W. and Snellgrove, T. A., 1993. An ecosystem perspective on sustainable forestry and new directions for the U.S. National Forest system. Pp. 44-89 in Defining sustainable forestry, edited by G. H. Aplet, N. Johnson, J. T. Olson and V. A. Sample, Island Press, Washington, D.C.

Saunders, D. A., Rowley, I. and Smith, G. T., 1985. The effects of clearing for agriculture on the distribution of cockatoos in the southwest of Western Australia. Pp. 309-321 in Birds of eucalypt forests and woodlands: ecology, conservation, management, edited by A. Keast, H. F. Recher, H. Ford and D. A. Saunders, Surrey Beatty and Sons, Chipping Norton, NSW. 
Saunders, D. A. and Ingram, J. A., 1995. Birds of southwesterm Australia; an atlas of changes in the distribution and abundance of the wheatbelt avifauna. Surrey Beatty and Sons, Chipping Norton, NSW.

Serageldin, I., 1993. Making development sustainable. Finance and Development 30: 6-10.

Seydack, A. H. W., 2000. Theory and practice of yield regulation systems for sustainable management of tropical and subtropical moist natural forests. Pp. 257-317 in Sustainable forest management, edited by K. von Gadow, T. Pukkala and M. Tome, Kluwer Academic Publishers, Dordrecht.

Shea, S. R., Gillen, K. J. and Kitt, R. J., 1978. Variation in sporangial production of Phytophthora cinnamomi Rands on jarrah (E. marginata $\mathrm{Sm}$ ) forest sites with different understorey compositions. Australian Forest Research 8: 219-226.

Shearer, B. L. and Tippett, J. T., 1989. Jarrah dieback: The dynamics and management of Phytophthora cinnamomi in the jarrah (Eucalyptus marginata) forest of south-western Australia. Research Bulletin No. 3, Department of Conservation and Land Management, Perth, Western Australia.

Stoate, T. N., 1926. Working Plan No. 1. Mundaring working circle. Forests Department of Western Australia, Perth, Western Australia.

Stoate, T. N., 1947. Forestry and forest resources Western Australia. Statement prepared for the fifth British Empire Forestry Conference (London). Forests Department of Western Australia, Perth, Western Australia.

Stoate, T. N., 1953. Report on the operations of the Forests Department for the year ended 30th June, 1953. Forests Department of Western Australia, Perth, Western Australia.

Stoneman, G.L., 1986. Wood generated by thinning in the northern jarrah forest. Australian Forestry 49: 115-121.

Stoneman, G. L., Rayner, M. E. and Bradshaw, F. J., 1997. Size and age parameters of nest trees used by four species of parrot and one species of cockatoo in south-western Australia: Critique. Ети 97: 94-96.

Stoneman, G. L., Bradshaw, F. J. and Christensen, P., 1989. Silviculture. Pp. 335-355 in The jarrah forest: a complex Mediterranean ecosystem., edited by B. Dell, J. J. Havel and N. Malajczuk, Kluwer Academic Publishers, Dordrecht.

Strehlow, K., Bradley, J. S., Davis, J. and Friend, G. R., 2002. Short term impacts of logging on invertebrate communities in jarrah forests in south-west Western Australia. Forest Ecology and Management 162: 165-184.

Thackway, R. and Cresswell, I. D., 1994. Toward an interim biogeographic regionalisation for Australia: a framework for setting priorities in the national reserves system cooperative program. Reserve Systems Unit, ANCA, Canberra.

Turner, B. J., 1998. An appraisal of methods and data used by CALM to estimate wood resource yields for the south-west forest region of Western Australia. Commonwealth and Western Australian Regional Forest Agreement Steering Committee, Canberra.

Turner, J. and Lambert, M., 1997. Development of indicators of sustainable development in Australia's forests. Pp. 471-475 in Conservation outside nature reserves, edited by $\mathrm{P}$. Hale and D. Lamb, Centre for Conservation Biology, The University of Queensland, Brisbane.

Turner, B., Ferguson, I. and Fitzpatrick, N. 1999. Report by the expert panel on the calculation of a sustainable sawlog yield for the jarrah and karri forests of W.A. Commonwealth and Western Australian Regional Forest Agreement Steering Committee, Canberra.
Underwood, R. J., 1983. Sustaining the yield. Forest Focus 30: 3-14.

Underwood, R.J. and Christensen, P., 1981. Forest fire management in Western Australia. Special Focus No 1, Forests Department of Western Australia.

van Bueren, E. and Blom, E., 1997. Hierarchical Framework for the Formulation of Sustainable Forest Management Standards: Principles, Criteria and Indicators, Leiden, The Netherlands, Tropenbos Foundation.

van Dieren, W. (Ed.), 1995. Taking nature into account. Copernicus, Springer Verlag, New York.

Vanclay, J., 1996. Assessing the Sustainability of Timber Harvests from Natural Forests: Limitations of indices Based on Successive Harvests. Journal of Sustainable Forestry 3: 47-58.

Varis, O. and Kuikka, S., 1997. Joint use of multiple environmental assessment models by a Bayesian meta-model - the Baltic salmon case. Ecological Modelling 102: 341-351.

Wallace, W. R., 1965. Fire in the jarrah forest environment. Journal of the Royal Society of Western Australia 49: 33-44.

Walters, C. J. and Holling, C. S., 1990. Large-scale management experiments and learning by doing. Ecology 71: 2060-2068.

Wardell-Johnson, G., 2000. Responses of forest eucalypts to moderate and high intensity fire in the Tingle Mosaic, southwestern Australia: comparisons between locally endemic and regionally distributed species. Austral Ecology 25: 409-421.

Wardell-Johnson, G. and Horwitz, P., 1996. Conserving biodiversity and the recognition of heterogeneity in ancient landscapes: a case study from south-western Australia. Forest Ecology and Management 85: 219-238.

Wardell-Johnson, G., Calver, M., Saunders, D., Conroy, S., and Jones, B. 2004. Why the integration of demographic and sitebased studies of disturbance is essential for the conservation of jarrah forest fauna, $\mathrm{Pp}$...... in Conservation of Australia's Forest Fauna (Second edition), edited by D. Lunney, Royal Zoological Society of New South Wales, Mosman, New South Wales.

Wardell-Johnson, G. and Horwitz, P., 2000. The recognition of heterogeneity and restricted endemism in the management of forested ecosystems in south-western Australia. Australian Forestry 63: 218-225.

Wardell-Johnson, G. and Nichols, O., 1991. Forest wildlife and habitat management in southwestern Australia: knowledge, research and direction. Pp. 161-192 in Conservation of Australia's forest fauna, edited by D. Lunney, Royal Zoological Society of New South Wales, Mosman, New South Wales.

Wardell-Johnson, G. and Roberts, J. D., 1991. The survival status of the Geocrinia rosea (Anura: Myobatrachidae) complex in riparian corridors: biogeographical implications. Pp. in Nature Conservation 2: The role of corridors, edited by D. A. Saunders and R. J. Hobbs, Surrey Beatty and Sons, Chipping Norton, New South Wales.

Wardell-Johnson, G., Williams, J., Hill, K. and Cummings, R., 1997. Evolutionary biogeography and contemporary distribution of eucalypts. Pp. 92-128 in Evolutionary biogeography and contemporary distribution of eucalypts, edited by J. Williams and J. Woinarski, Cambridge University Press, Cambridge.

Yaffee, S. L., 1994. The wisdom of the Spotted Owl: policy lessons for a new century. Island Press, Washington, DC.

Young, J. T., 1994. The future - effects of plant disease on society. Journal of the Royal Society of Western Australia 77: 185-186. 